OAK RIDGE

NATIONAL

LABORATORY

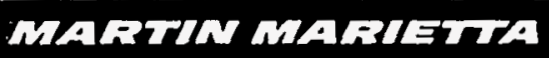

A Low-Temperature Process for the Denitration of Hanford Single-Shell Tank, Nitrate-Based Waste Utilizing the Nitrate to Ammonia and Ceramic (NAC) or Nitrate to Ammonia and Glass (NAG) Process: Phase II Report
A. J. Mattus

J. F. Walker, Jr.

E. L. Youngblood

L. L. Farr

D. D. Lee

T. A. Dillow

T. N. Tiegs

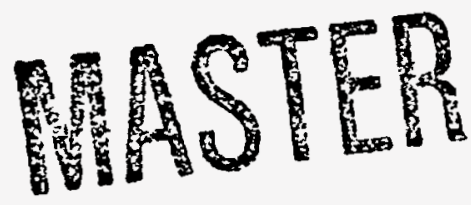




\title{
A LOW-TEMPERATURE PROCESS FOR THE DENTTRATION OF HANFORD SINGLE-SHELL TANK, NITRATE-BASED WASTE UTILIZING THE NITRATE TO AMMONIA AND CERAMIC (NAC) OR NITRATE TO AMMONIA AND GLASS (NAG) PROCESS: PHASE II REPORT
}

\author{
A. J. Mattus \\ J. F. Walker, Jr. \\ E. L. Youngblood \\ L. L. Farr \\ Engineering Development Section \\ Chemical Technology Division \\ D. D. Lee \\ T. A. Dillow \\ Chemical Development Section \\ Chemical Technology Division \\ T. N. Tiegs \\ Metals and Ceramics Division
}

Date published: December 1994

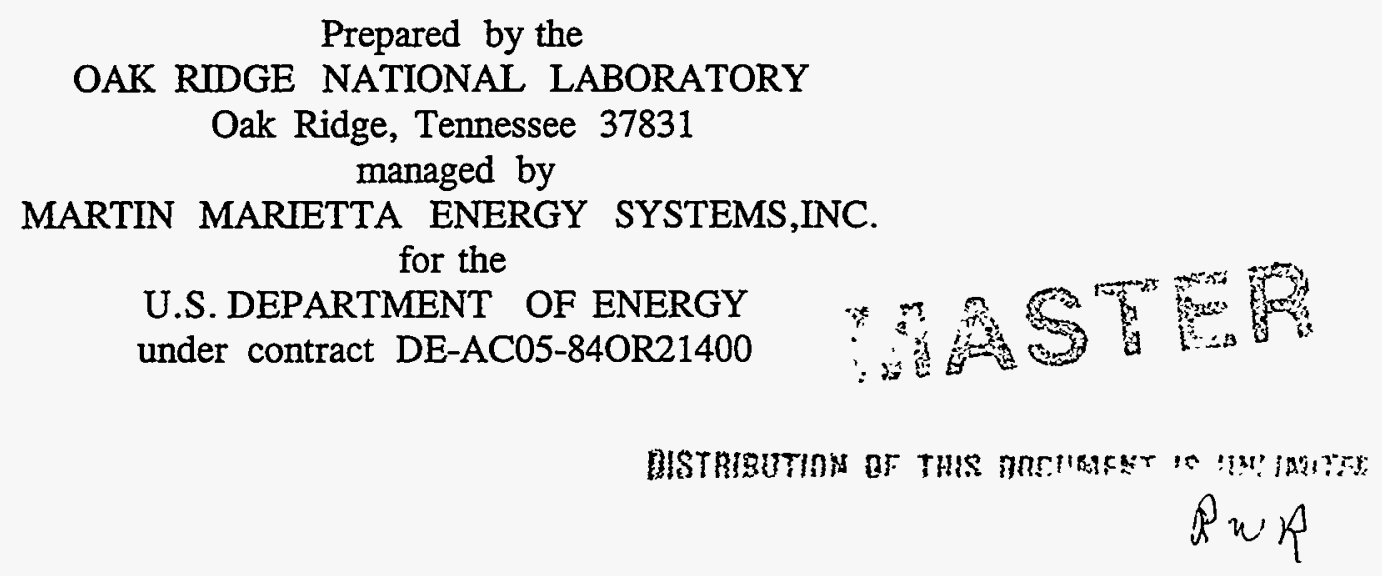

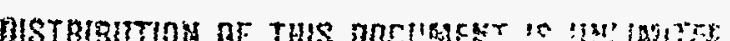
$R w R$ 


\section{DISCLAIMER}

This report was prepared as an account of work sponsored by an agency of the United States Government. Neither the United States Government nor any agency thereof, nor any of their employees, make any warranty, express or implied, or assumes any legal liability or responsibility for the accuracy, completeness, or usefulness of any information, apparatus, product, or process disclosed, or represents that its use would not infringe privately owned rights. Reference herein to any specific commercial product, process, or service by trade name, trademark, manufacturer, or otherwise does not necessarily constitute or imply its endorsement, recommendation, or favoring by the United States Government or any agency thereof. The views and opinions of authors expressed herein do not necessarily state or reflect those of the United States Government or any agency thereof. 


\section{DISCLAIMER}

Portions of this document may be illegible in electronic image products. Images are produced from the best available original document. 


\section{CONTENTS}

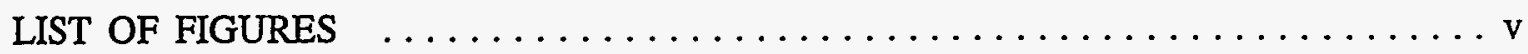

LIST OF TABLES $\ldots \ldots \ldots \ldots \ldots \ldots \ldots \ldots \ldots \ldots \ldots \ldots \ldots \ldots \ldots \ldots \ldots$

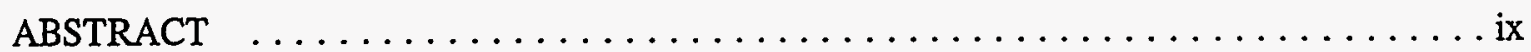

1. INTRODUCTION $\ldots \ldots \ldots \ldots \ldots \ldots \ldots \ldots \ldots \ldots \ldots \ldots \ldots \ldots$

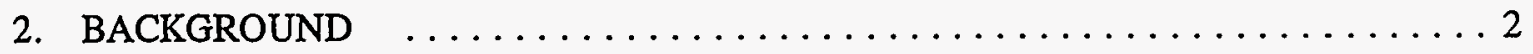

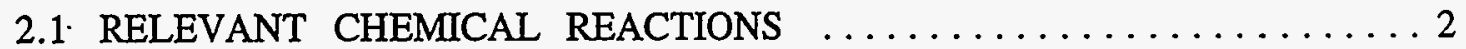

2.2 PROPERTIES OF REACTOR PRODUCTS $\ldots \ldots \ldots \ldots \ldots \ldots \ldots \ldots \ldots$

2.3 POTENTIAL FOR VOLUME REDUCTION $\ldots \ldots \ldots \ldots \ldots \ldots \ldots \ldots \ldots$

2.4 FATE OF OTHER WASTE SOLUTION CATIONS $\ldots \ldots \ldots \ldots \ldots \ldots 7$

2.5 NAC REACTOR OFF-GASES $\ldots \ldots \ldots \ldots \ldots \ldots \ldots \ldots \ldots \ldots \ldots \ldots \ldots \ldots$

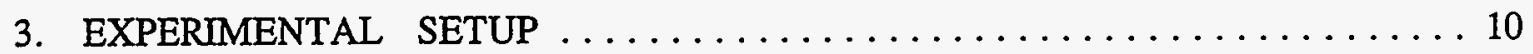

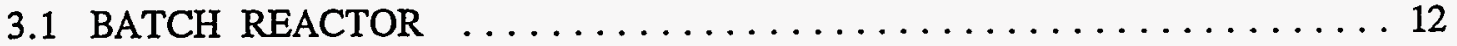

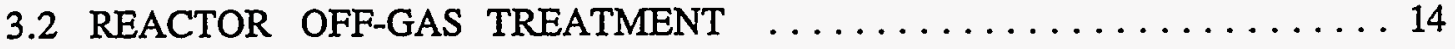

4. WASTE STREAMS EVALUATED BY THE NAC PROCESS $\ldots \ldots \ldots \ldots$

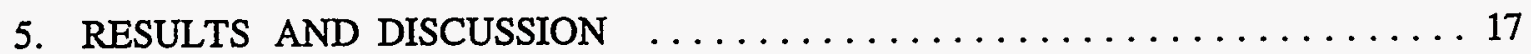

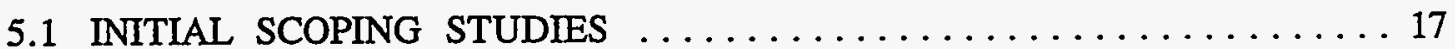

5.2 WASTE-FORM PREPARATION AND EVALUATION $\ldots \ldots \ldots \ldots \ldots 19$

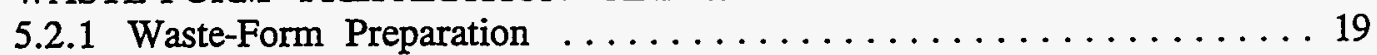

5.2 .2 Leach Testing . . . . . . . . . . . . . . . . . 30

5.2.3 Leaching NAC Product Produced from MVST-W-26 Supernate . . . . 32

5.3 RESULTS OF CONTINUOUS REACTOR TEST .............. 34

5.4 HYDROGEN PRODUCTION IN THE NAC PROCESS $\ldots \ldots \ldots \ldots \ldots \ldots 35$

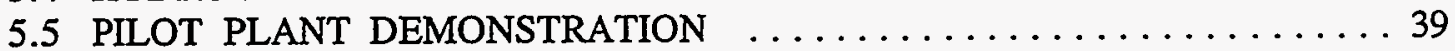

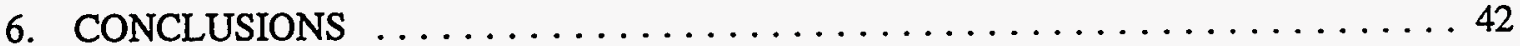

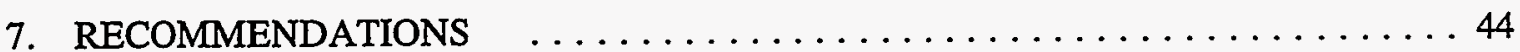

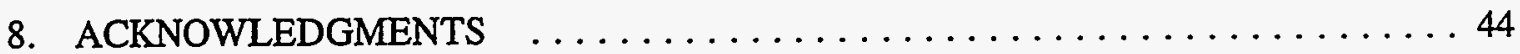

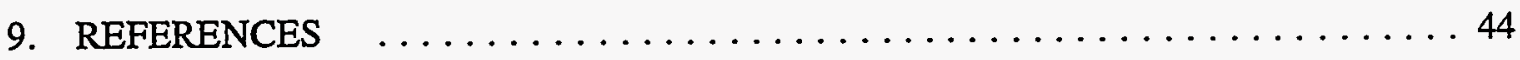

iii 


\section{LIST OF FIGURES}

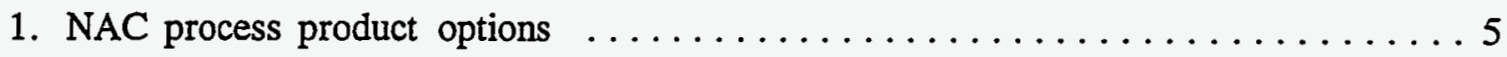

2. Relative volume reduction efficiencies: a comparison of grouting with the NAC

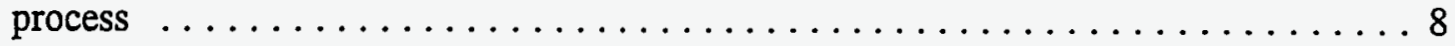

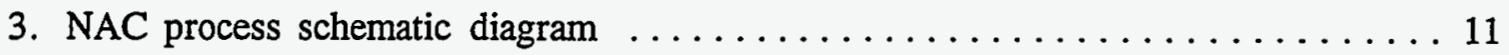

4. Experimental apparatus for continuous laboratory NAC process $\ldots \ldots \ldots \ldots 13$

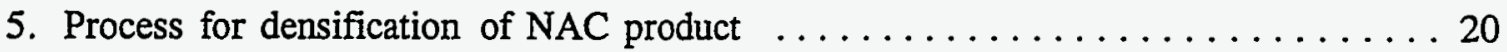

6. Weight loss as a function of temperature for NAC product (sample is AW-9) $\ldots 23$

7. Scanning electron micrograph of NAC product after calcination (sample AW-1) . 24

8. Densification summary of NAC product from sodium nitrate solutions $\ldots \ldots \ldots 28$

9. Densification summary of NAC product from salt cake solution. . . . . . . . 29

10. Hydrogen production during $\mathrm{NAC}$ run $\ldots \ldots \ldots \ldots \ldots \ldots \ldots \ldots \ldots \ldots \ldots \ldots \ldots$

11. Hydrogen production near the end of the reaction $\ldots \ldots \ldots \ldots \ldots \ldots \ldots$

12. NAC pilot demonstraton unit material balance and flow diagram ........ 40

13. Material balance flowsheet for the NAC pilot plant $\ldots \ldots \ldots \ldots \ldots \ldots \ldots \ldots$ 



\section{LIST OF TABLES}

1. Composition of Hanford dry synthetic SST salt cake $\ldots \ldots \ldots \ldots \ldots \ldots$

2. Surrogate representing MVST W-26 (1985) run $\ldots \ldots \ldots \ldots \ldots \ldots \ldots \ldots$

3. NAC compositions used in densification study and calcination weight losses.

The theoretical content is based on amount needed to form

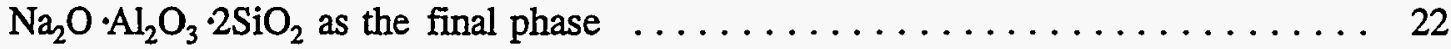

4. Summary of densification results on materials made from sodium nitrate solution and containing no added silica. AW-1 through AW-4 $\ldots \ldots \ldots \ldots .25$

5. Summary of densification results on materials made from sodium nitrate solution and containing silica additions. AW-5 through $\mathrm{AW}-13 \ldots \ldots \ldots \ldots \ldots \ldots$

6. Summary of densification results on materials made from salt cake solution and containing silica additions. AW-14 through AW-21 $\ldots \ldots \ldots \ldots \ldots \ldots 27$

7. Ninety-day sodium cation leaching test results from ceramic forms of

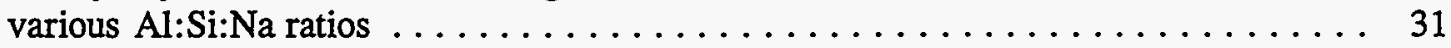

8. MVST W-26 NAC pellets after calcining and sintering $\ldots \ldots \ldots \ldots \ldots \ldots$

9. Leaching results for MVST $\mathrm{W}-26$ Supernate $\ldots \ldots \ldots \ldots \ldots \ldots \ldots \ldots \ldots \ldots$

10. Toxicity characteristic leaching procedure (TCLP) test results of sintered

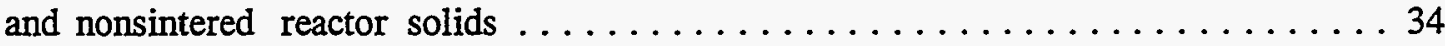

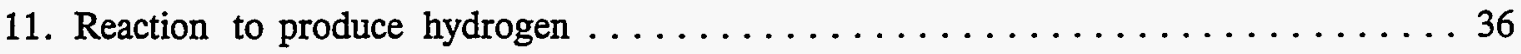





\begin{abstract}
Continuing benchtop studies using Hanford single-shell tank (SST) simulants and actual Oak Ridge National Laboratory (ORNL) low-level waste (LLW), employing a new denitration process for converting nitrate to ammonia and ceramic (NAC), have conclusively shown that between 85 and $99 \%$ of the nitrate can be readily converted to gaseous ammonia. In this process, aluminum powders can be used to convert alkaline, nitratebased supernate to ammonia and an aluminum oxide-sodium aluminatebased solid. The process may be able to use contaminated aluminum scrap metal from Department of Energy (DOE) sites to effect the conversion. The final, nitrate-free ceramic product can be pressed and sintered like other ceramics or silica and/or fluxing agents can be added to form a glassy ceramic or a flowable glass product. Based upon the starting volumes of 6.2 and $3.1 \mathrm{M}$ sodium nitrate solution (probable supernate concentrations resulting from salt-cake/sludge removal from the Hanford SSTs), volume reductions of 50 to $70 \%$ were obtained for the waste form produced.
\end{abstract}

Sintered pellets produced from supernate from Melton Valley Storage Tanks (MVSTs) have been leached in accordance with the NRC's American Nuclear Society (ANS) 16.1 leach test for the radioelements ${ }^{85} \mathrm{Sr}$ and ${ }^{137} \mathrm{Cs}$. Despite lengthy counting times, ${ }^{85} \mathrm{Sr}$ could not be detected in the leachates. ${ }^{137} \mathrm{Cs}$ was only slightly above background and corresponded to a leach index of 12.2 to 13.7 after 8 months of leaching. Leach testing of unsintered and sintered reactor product spiked with hazardous metals of interest to the Environmental Protection Agency (EPA) proved that both sintered and unsintered product passed the Toxicity Characteristic Leaching Procedure (TCLP) test.

Design of the equipment and flowsheet for a pilot demonstration-scale system to prove the nitrate destruction portion of the NAC process and product formation is under way. The reaction of nitrate solution with aluminum powder will occur in a single-stage, continuous-stirred-tank backmix reactor. Silica powder will be added to the reactor to later immobilize the alkali metals during the ceramic- or glassmaking step. A centrifuge will be used to remove solid products from the recycle stream. The heat of reaction will be removed by circulating a stream from the reactor through a heat exchanger; reaction conditions will be atmospheric pressure and between $50-70^{\circ} \mathrm{C}$. 


\title{
A LOW-TEMPERATURE PROCESS FOR THE DENTTRATION OF HANFORD SINGLE-SHELL TANK, NITRATE-BASED WASTE UTILIZING THE NITRATE TO AMMONIA AND CERAMIC (NAC) OR NITRATE TO AMMONIA AND GLASS (NAG) PROCESS: PHASE II REPORT
}

\author{
A. J. Mattus, J. F. Walker, Jr., E. L. Youngblood, and L. L. Farr \\ Engineering Development Section \\ Chemical Technology Division \\ D. D. Lee and T. A. Dillow \\ Chemical Development Section \\ Chemical Technology Division \\ T. N. Tiegs \\ Metals and Ceramics Division
}

\section{INTRODUCTION}

Sodium nitrate-based wastes are common to many Department of Energy (DOE) facilities throughout the United States. Examples are the single-shell tanks (SSTs) at the Hanford site, waste at the Savannah River site, the Melton Valley Storage Tanks (MVSTs) at the Oak Ridge National Laboratory (ORNL), the Rocky Flats waste, and the Pad A Waste at Idaho Falls. Data from 1984 show that approximately 242,700 metric tons of nitrate wastes were stored at these facilities. The majority of this waste is located in the Hanford SSTs, of which there are 149 tanks with capacities of up to 1 million gal each.

Because the nitrate anion and sodium cation are very mobile and difficult to immobilize, especially in relatively porous, cement-based grout, efforts are under way to develop better waste forms for cleanup efforts at Hanford and other DOE sites. Processes that decompose nitrate might eliminate this species and, therefore, be of interest to DOE, as well as to federal and state regulators. One such process is the nitrate to ammonia and ceramic (NAC) process under development at ORNL. ${ }^{1,2}$ The NAC process uses aluminum to reduce nitrate, producing a ceramic product and an ammonia off-gas.

This report describes the work accomplished to date in this second phase of the NAC process development, which includes the following: 
(1) a summary of the process chemistry and the major accomplishments for FY 1992,

(2) the results from batch and continuous bench-scale reactor studies, and

(3) the results of leaching studies and waste-form evaluation of the NAC ceramic product.

\section{BACKGROUND}

\subsection{RELEVANT CHEMICAL REACTIONS}

In the NAC process, aluminum dissolves, functioning similarly to a sacrificial anode, and the following equation can be written for the sodium nitrate reduction reaction assuming $100 \%$ efficiency:

$$
3 \mathrm{NaNO}_{3}+8 \mathrm{Al}+12 \mathrm{H}_{2} \mathrm{O} \rightarrow 3 \mathrm{NH}_{3} \uparrow+2.5 \mathrm{Al}_{2} \mathrm{O}_{3} \cdot 3 \mathrm{H}_{2} \mathrm{O} \downarrow+3 \mathrm{NaAlO}_{2} .
$$

The equation, as written, reveals that (1) if $100 \%$ efficient, $0.85 \mathrm{~kg}$ of metal would be required per $\mathrm{kg}$ of sodium nitrate $(8$ moles of aluminum for each 3 moles of sodium nitrate); (2) the reaction does not show sodium hydroxide as a product; (3) the product would contain $61 \%$ gibbsite as $\mathrm{Al}_{2} \mathrm{O}_{3} \cdot 3 \mathrm{H}_{2} \mathrm{O}$ and $39 \%$ sodium aluminate; and (4) the reaction consumes 4 moles of water per mole of nitrate converted.

Upon first adding aluminum metal to a solution that is alkaline $(\mathrm{pH} 12.5)$ and contains nitrate anions, one obtains an initial delay in reactivity and then a reaction that is associated with a rapid increase in temperature. The temperature increases because the reduction of nitrate to ammonia with the conversion of aluminum metal to oxide is exothermic with a calculated heat of reaction of $-1.595 \mathrm{MJ} / \mathrm{mole}$ of sodium nitrate. During the eaily stage of the reaction, the solution remains clear until the solubility of aluminate is exceeded, and then dense white gibbsite $\left(\mathrm{Al}_{2} \mathrm{O}_{3} \cdot 3 \mathrm{H}_{2} \mathrm{O}\right)$ begins to precipitate. Upon stopping the mixer, the solids quickly settle to the bottom of the reactor, much like sand. As aluminum metal is added to the alkaline solution in the $\mathrm{pH}$ range of $12.5-14$, soluble aluminate anions predominate until after a sufficiently large quantity of aluminum has reacted and the soluble aluminate/gibbsite precipitate equilibrium is reached. After the solution reaches this point, any further addition of aluminum metal causes the 
continuous formation of the highly insoluble gibbsite product. The solubility minimum for the aluminum ion occurs at $\mathrm{pH} 5$. Although the reaction may take place at this lower $\mathrm{pH}$, the increase in the concentration of the hydrogen cation will cause the aluminum to preferentially react with it instead of with nitrate and, therefore, waste aluminum by forming hydrogen gas. Consequently, the reactor must operate at higher $\mathrm{pH}$ values to have a viable process.

Laboratory tests have shown that excess aluminum must be added to reduce the nitrate to low concentrations. When operated on a semicontinuous basis, the actual aluminum used to produce a $1000-\mathrm{mg} / \mathrm{L}$ nitrate residual from a 3 to $4 M$ solution is $\sim 110 \%$ of the theoretical requirement to reduce all the nitrate. This results in a nitrate conversion of $-99.5 \%$.

The excess aluminum reduces the hydrogen component of water to hydrogen gas. Batch tests have shown that some hydrogen is produced when the aluminum is first added to the reactor before any gibbsite has formed; however, most of the hydrogen is produced at the end of the reaction when the nitrate concentration is low in comparison with the concentration of water. Tests are currently being conducted at a bench scale using a continuous-stirred-tank reactor (CSTR) to refine the NAC process and determine operating conditions necessary to reduce the required excess aluminum and to reduce or eliminate the hydrogen gas produced. Based on work to date, these conditions seem to be: (1) at least a 1000-mg/L residual nitrate concentration, (2) enough liquid to provide efficient mixing, and (3) a solution saturated with respect to aluminate. Experimental data to date, based on the above operating conditions and $10 \%$ excess aluminum, yield the following stoichiometric equation for the NAC process:

$3 \mathrm{NaNO}_{3}+8.8 \mathrm{Al}+14.4 \mathrm{H}_{2} \mathrm{O} \rightarrow 3 \mathrm{NH}_{3} \uparrow+1.2 \mathrm{H}_{2} \uparrow+2.9 \mathrm{Al}_{2} \mathrm{O}_{3} \cdot 3 \mathrm{H}_{2} \mathrm{O} \downarrow+3 \mathrm{NaAlO}_{2}$.

\subsection{PROPERTIES OF REACTOR PRODUCTS}

The solid product from the reaction of aluminum metal with a basic solution of sodium nitrate after oven drying, based on analytical results, is gibbsite with a small percentage $(3-4 \%)$ of sodium aluminate and a trace amount of caustic. This product is sandlike and easily dewatered. If allowed to stand in the reactor for many hours, it will "age," become quite hard, and afterward cannot even be dissolved in acid. After this type 
of aging, in which three-dimensional bonding between aluminum, oxygen, and some hydrogen occurs, the product can be dissolved in boiling sodium hydroxide solutions only with difficulty.

The reaction product can be dried and then calcined and sintered at various temperatures to produce different types of alumina ( $\alpha-, \beta-, \gamma$-alumina) with different properties. Each of the higher forms of alumina becomes successively more chemically inert following calcination and sintering (gibbsite-stable below $155^{\circ} \mathrm{C}$, boehmite-stable below $280^{\circ} \mathrm{C}$, corundum-melts at $2020^{\circ} \mathrm{C}$ ). In addition, higher-temperature sintering of alumina causes fusion to occur between the particles where contact between them is made, thereby increasing the physical strength and increasing the density of the form.

In some of the work, enough silica has been added to the reactor feed to form a mineral compound containing a sodium-silica-alumina ratio of $1: 1: 1$ when the reactor product is sintered. This mineral form, known as nepheline, acts to immobilize the sodium, which remains following the sodium nitrate reduction, in the final product.

Since both alumina and silica are present in three major classes of materials, that is (1) ceramics, (2) glass ceramics, and (3) various types of glass, the flexibility exists to produce any of these material types. The process options are shown schematically in Fig. 1. As shown, the NAC product is actually a glassy ceramic, and the NAG product is a flowable glass.

A ceramic product can be produced from the reactor product by heating to remove chemically bound water and to react the $\mathrm{Na}, \mathrm{Al}$, and $\mathrm{Si}$ (if present) components to form a dense material that is resistant to environmental degradation. To produce a glassceramic, additional silica must be added and the product must be sintered to fuse the reactor products. A glass ceramic is typically composed of $62-70 \%$ silica, $17-22 \%$ alumina, and $3-5 \%$ sodium or lithium oxide. ${ }^{3}$ To form a glass requires additional silica and sintering. Fluxing agents, such as boron oxide, are sometimes added to improve the glass processing parameters, such as melt temperature and viscosity. A typical soda-lime-silica glass would contain $70-74 \%$ silica, $0.5-4.5 \%$ alumina, $5-16 \%$ lime, and a fluxing agent.

At the present time, $150 \%$ of the theoretical quantity of silica required to form a nepheline product is added to the NAC reactor. This ceramic product currently contains approximately $50 \% \mathrm{SiO}_{2}, 30 \% \mathrm{Al}_{2} \mathrm{O}_{3}$, and $18 \% \mathrm{Na}_{2} \mathrm{O}$. The reactor discharge can be 


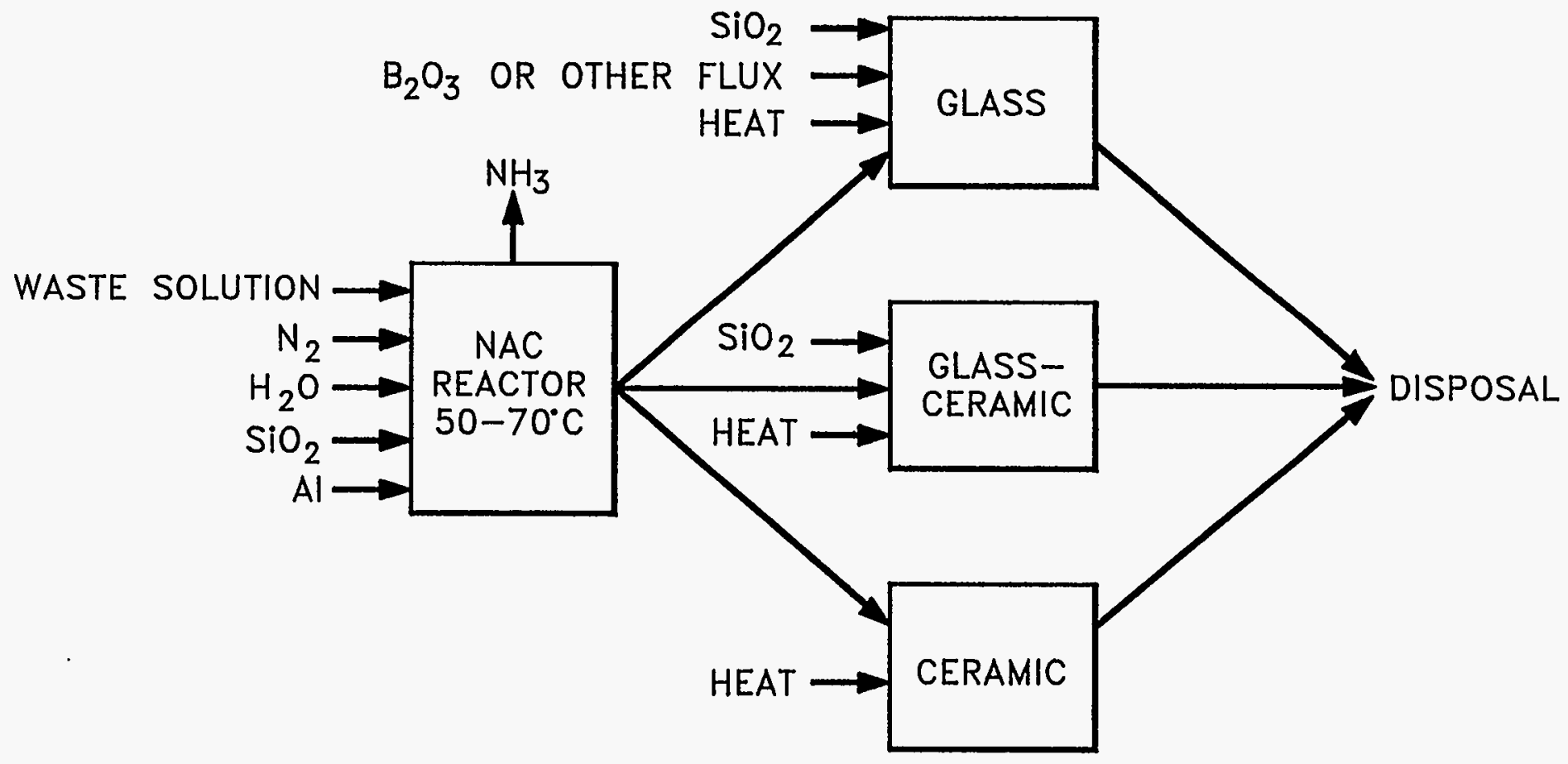

Fig. 1. NAC process product options. 
altered to produce any of the above waste forms by adding the appropriate ratios of silica and fluxing agents. From the products of reaction (2), the ceramic can be formed by adding the desired amount of silica in the form of powdered quartz, followed by calcining and sintering, as shown in reaction (3):

$2.9 \mathrm{Al}_{2} \mathrm{O}_{3} \cdot 3 \mathrm{H}_{2} \mathrm{O}+3 \mathrm{NaAlO}_{2}+4.5 \mathrm{SiO}_{2} \rightarrow 1.5\left(\mathrm{Na}_{2} \mathrm{O} \cdot[8.8] / 3 \mathrm{Al}_{2} \mathrm{O}_{3} \cdot 3 \mathrm{SiO}_{2}\right)+8.7 \mathrm{H}_{2} \mathrm{O}$

Work is currently under way to develop the most suitable waste form for Hanford SSTs and other DOE nitrate-based wastes.

\subsection{POTENTIAL FOR VOLUME REDUCTION}

Studies have been conducted with product from the NAC reactor using sodium nitrate feed concentrations ranging from 1.55 to $6 \mathrm{~mol} / \mathrm{L}$ to gauge volume changes based upon the starting waste volume. These studies have been based on a steady state conversion to $1000 \mathrm{mg} / \mathrm{L}$ nitrate using $110 \%$ of the aluminum theoretically required for complete conversion of the nitrate. This means $0.8-1.6 \mathrm{~kg} \mathrm{Al} / \mathrm{kg} \mathrm{NaNO}$ was used. It should be noted that for those tank wastes that contain large amounts of nitrite, less aluminum will be required. That is, 2 moles of aluminum per mole nitrite is needed to convert this species to ammonia, compared to nitrate which requires 2.67 moles of aluminum per mole.

In early tests, the reactor product was dried at $110^{\circ} \mathrm{C}$ and then pressed uniaxially at 5000 psi for a final volume reduction of $55 \%$; that is, one unit volume of waste $(1 \mathrm{~L}$ of $4 \mathrm{MNaNO}_{3}$ ) became 0.45 unit volumes ( $450 \mathrm{~mL}$ ) of hard solid.

In later tests, calcining the reactor product at $700-800^{\circ} \mathrm{C}$ followed by uniaxially pressing the ground calcined product at 10,000 psi was studied. In these tests, $100 \%$ of the theoretical densities for the products was achieved. The above tests were conducted without the addition of silica.

Studies have also been conducted with silica added to the reactor product. In some studies, enough silica ( 1 mole silica per mole of sodium) was added to the product to form the mineral nepheline $\left(\mathrm{Na}_{2} \mathrm{O} \cdot \mathrm{Al}_{2} \mathrm{O}_{3} \cdot 2 \mathrm{SiO}_{2}\right)$ upon calcining and sintering. In other tests, up to $150 \%$ of the quantity of silica necessary to form nepheline was added. The nepheline acts to immobilize the sodium produced during the sodium nitrate reduction. 
Theoretical densities of $2.6-3.0 \mathrm{~g} / \mathrm{cm}^{3}$, depending on the silica content, have been obtained for the calcined and sintered product at a sintering temperature of $1225^{\circ} \mathrm{C}$.

The NAC process is currently able to achieve volume reductions of $70 \%$ based upon the starting volume of a $4 M$ sodium nitrate solution. If nitrate-based waste is immobilized in a cement-based grout, as is done at the Savannah River Plant or at Oak Ridge's MVSTs, a volume increase between 35 and 50\%, depending on the formulation used, can be expected. In ORNL's Melton Valley $\sim 4 M$ sodium nitrate is being grouted, and a volume increase of $-38 \%$ is occurring. A schematic comparison of the relative volume reduction efficiencies of the NAC process as compared to grout is presented in Fig. 2.

If lower concentrations, such as, for example, $3 \mathrm{M}$ sodium nitrate, are treated at Hanford or other DOE sites, a larger volume reduction can be expected. Additionally, since much of the Hanford supernate contains nitrite in addition to nitrate, less aluminum metal may be required to reduce this species and additional volume reduction can be expected.

\subsection{FATE OF OTHER WASTE SOLUTION CATIONS}

The NAC process has an added bonus besides converting nitrate to ammonia; that is, it also precipitates most cations from solution forming "highly"insoluble aluminates. Since aluminate is an important intermediate species in the reaction, this anion is always present and forms what are called "spinels" in the material science field. These spinels for mono and divalent cations are represented as $\mathrm{R}_{2} \mathrm{O} \cdot 11 \mathrm{Al}_{2} \mathrm{O}_{3}$ and $\mathrm{RO} \cdot 6 \mathrm{Al}_{2} \mathrm{O}_{3}$, respectively, and can include $\mathrm{Mg}, \mathrm{Ni}, \mathrm{Zn}, \mathrm{Mn}, \mathrm{Cr}, \mathrm{Fe}, \mathrm{Cu}, \mathrm{Ca}, \mathrm{Co} \mathrm{Ti}, \mathrm{Sn}$, etc. In fact, the spinel calcium aluminate, is the active ingredient in portland cement $(\sim 10 \%)$ and is quite insoluble. The sister alkaline earth species, strontium, also forms a spinel with properties similar to those of calcium, and it has been shown that strontium is completely immobilized in the reactor product without calcining or sintering. The higher the ratio of positive charge to ionic radius of the cation, the more insoluble is the resulting spinel. ${ }^{4.5}$ This means that metal ions with a +3 charge, such as chromium, would be more insoluble than calcium. This fortunate chemical property of aluminum means that many metal and nonmetal cations will enter the dense, solid ceramic matrix as a very insoluble mineral. 


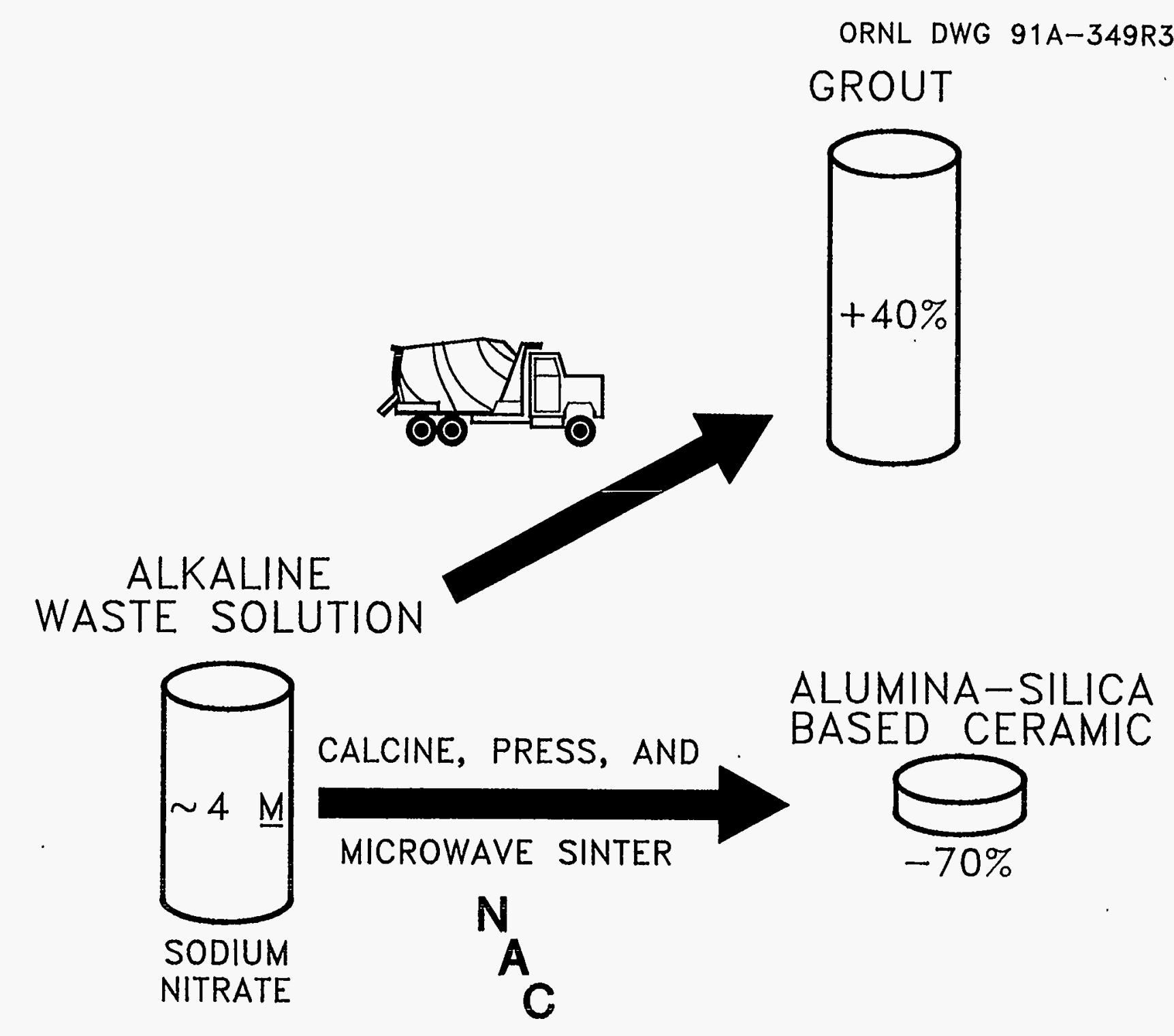

Fig. 2. Relative volume reduction efficiencies: a comparison of grouting with the NAC process. 
Unfortunately, sodium and the alkali metals do not appreciably react to form the spinels under the conditions in our reactor.

As discussed earlier in this report and detailed in the first phase report, ${ }^{6}$ fine silica in the form of 35- to $40-\mu \mathrm{m}$ quartz is added to the reactor at the time that aluminum is added for the purpose of immobilizing the very mobile, alkali metal component of the waste as nepheline upon sintering. The formula for the sodium form of the nepheline mineral phase, $\mathrm{Na}_{2} \mathrm{O} \cdot \mathrm{Al}_{2} \mathrm{O}_{3} \cdot 2 \mathrm{SiO}_{2}$, implies from its stoichiometry that, at a minimum, 1 mole of silica for each mole of sodium that is present in the initial waste solution will be required to bind sodium in this phase. Adding silica above the amount necessary to form nepheline produces a glassy phase that qualifies the ceramic as a "glassy" ceramic much like many ceramics used in industry.

The excess added quartz forms a glass that serves to bind together crystalline grains. Most ceramics do not consist of a single crystal but are composed of numerous crystals joined to form polycrystalline structures. Most of the ceramics produced are mixtures of crystalline grains and a glassy phase that frequently acts as the bond.

It is expected that some sodium associated with the sodium aluminate may also dissolve in the glass as oxide, as would the aluminum associated with this salt. This dissolution into the excess glassy phase can only be made through the respective oxides of sodium and aluminum, for only oxides are soluble in glasses up to their solubility limits in this medium.

At the high temperatures associated with sintering, we can expect that excess glass will become a solvent for oxides of sodium and aluminum. In addition, excess silica also serves to further lower the fusion point of our alumina-silica-sodium oxide-based ceramic form as do the presence of ionic salts associated with the waste solution. Now, when using the theoretical amount of aluminum to reduce nitrate to ammonia, which is $0.847 \mathrm{~kg}$ $\mathrm{Al} / \mathrm{kg} \mathrm{NaNO}_{3}$, and a silica to total sodium molar ratio of $1.5: 1$, we find that we require a sintering temperature of $1225^{\circ} \mathrm{C}$. At this temperature, reactor solids quickly densify to an approximate density of $2.8 \mathrm{~g} / \mathrm{cm}^{2}$.

\subsection{NAC REACTOR OFF-GASES}

Ammonia is the primary gas produced from the NAC reactor with small amounts of hydrogen possible. In laboratory tests, the ammonia has been scrubbed with dilute 
hydrochloric acid. Present plans for scaleup include recovery and disposal of ammonia by scrubbing into dilute sulfuric acid to form ammonium sulfate. Many options are available for handling the ammonia off-gas using "off-the-shelf" technology, as briefly discussed in last year's technical memorandum report. ${ }^{6}$ These technologies include the following:

(1) The ammonia can be scrubbed into dilute acid to form ammonium salts.

(2) The gas can be cooled and pressurized into liquid ammonia for reuse.

(3) The ammonia can be re-oxidized to form nitric acid for reuse on site.

(4) The ammonia can be burned in a heated, catalytic bed tower to nitrogen and water vapor. ${ }^{7,8}$

On a larger scale at the Hanford site, during actual implementation of this process, the best option might be to consider catalytic conversion of ammonia to nitrogen and water vapor. These end products would possibly be preferred to creating another secondary, aqueous waste stream from scrubbing operations which would require storage and treatment.

A schematic diagram is presented in Fig. 3 showing how the technology could be coupled with the NAC process. The conversion of gaseous ammonia to nitrogen and water vapor is a standard, two-step commercial operation that employs first an oxidative step to form $\mathrm{NO}_{x}$ by reaction with air and then reduction with a slip stream of ammonia to nitrogen and water vapor. In this process air is mixed with the ammonia, preheated to $315^{\circ} \mathrm{C}$, and then passed over a vanadium oxide-titanium oxide catalyst bed that heats to $650^{\circ} \mathrm{C}$ due to the heat of oxidation. The $\mathrm{NO}_{\mathrm{x}}$ formed at 95 to $99 \%$ efficiency is again preheated to $315^{\circ} \mathrm{C}$ and passed over a similar reductive catalyst that heats to $427^{\circ} \mathrm{C}$ due to the reaction heat, forming nitrogen and water vapor at a $95 \%$ efficiency. ${ }^{8}$

\section{EXPERIMENTAL SETUP}

Initial testing of the NAC process was done in a bench-scale, batch reactor. After completion of the batch reactor studies, a continuous bench-scale reactor was designed and constructed for further evaluation of the process. 


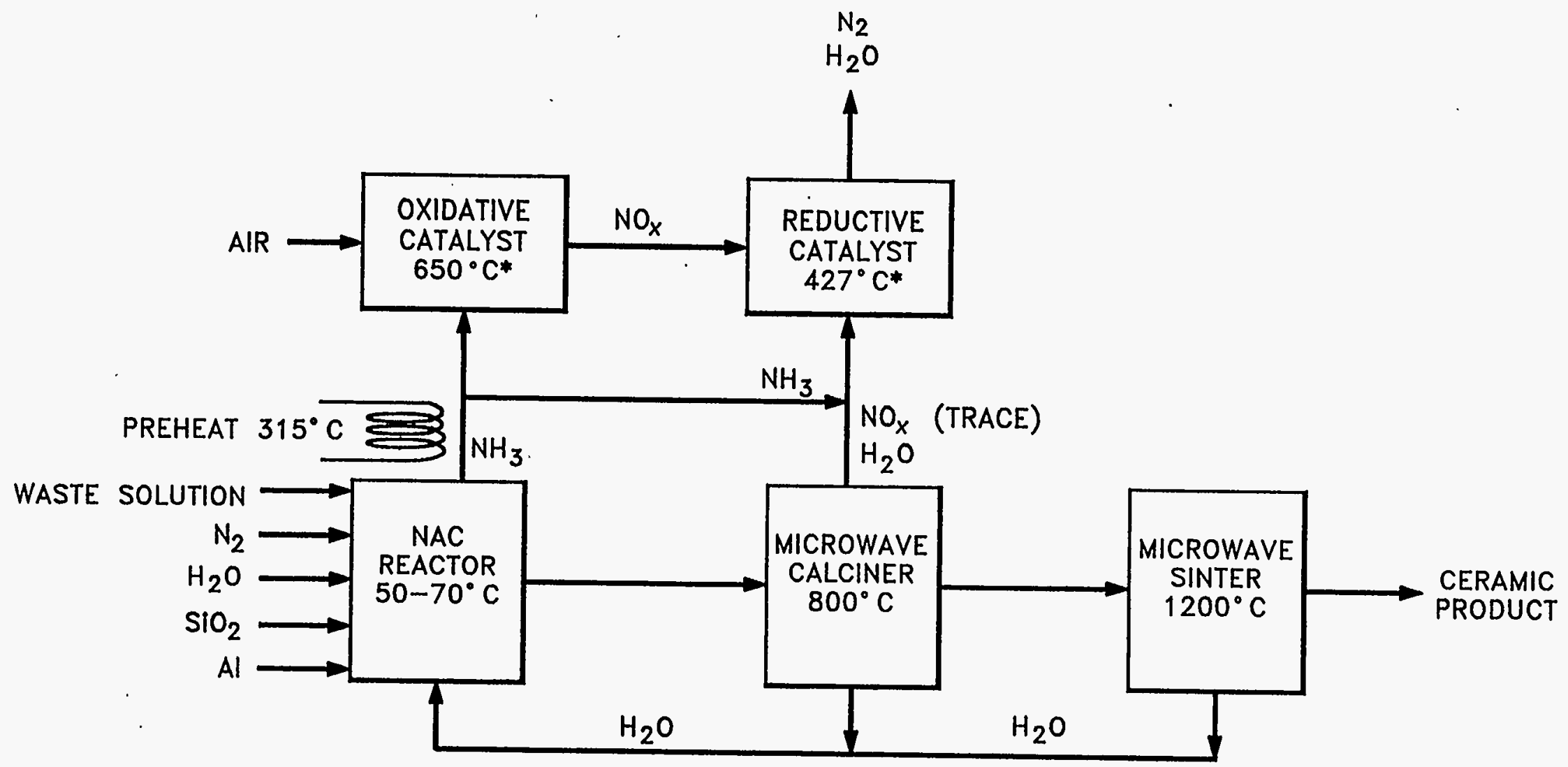

*Steady-state temperature from the heat of reaction

Fig. 3. NAC process schematic diagram. 


\subsection{BATCH REACTOR}

The reactor system used in the initial testing of the NAC process was a stirredtank batch reactor. It contains a four-bladed, magnetically driven stainless steel (SS) turbine agitator, four SS baffles, an electrical heating rod with temperature controller, and various lid openings for other equipment. For these tests, a 1.52-m-long cooling coil was constructed of 3.2-mm-OD SS tubing and inserted into the reaction area of the vessel. Cooling was provided by a Lauda $\mathrm{K}-4 / \mathrm{R}$ refrigerated circulating bath of $1600-\mathrm{W}$ cooling capacity. For pH monitoring, an Orion semimicro Ross glass combination electrode was placed into the vessel during the reaction. An Orion model $920 \mathrm{~A} \mathrm{pH}$ meter was used as the indicator and connected to a Linear recorder for a record of the $\mathrm{pH}$ during the reaction. A 3.2-mm SS Type $\mathrm{K}$ thermocouple was connected to an Omega monitor and Linear recorder to monitor the reaction temperature.

The aluminum was fed to the reactor as small pellets or powders with an Ace Glass model B7234 powder-dispensing funnel driven by a Cole-Parmer Servodyne powerdrive system. The powder-dispensing funnel could dispense powders from 25 mesh $(0.7 \mathrm{~mm})$ to 270 mesh $(0.002 \mathrm{~mm})$. Particles smaller than 270 mesh tended to plug and not feed. Midrange-size (60-130 mesh) particles fed very uniformly and predictably. To keep the finest, feedable powders from caking in the small-diameter feed lines due to moisture from the reactor, dry nitrogen was fed through the powder feed tube and through the reactor. Small powders were also fed using a slurry of the aluminum powder in neutral-pH water. This resulted in much less line plugging at high reaction rates while also providing water necessary for the reaction.

Due to the small volumes of material in the bench-scale batch reactor, continuous operation was simulated by using periodic feed and withdrawal of product. This prevented buildup of reactants in the reactor to concentrations which could cause reactor boil over.

The reactor designed for continuous-flow experiments is similar to the batch reactor configuration used previously and is shown in Fig. 4. This reactor is a $500-\mathrm{mL}$ glass vessel with a screw on top containing the openings for the various feed and product streams and the agitator shaft. The reactor is placed in a water bath for temperature control and contains a type- $\mathrm{K}$ thermocouple for monitoring of reaction temperature. Nitrate liquid feed is pumped from the reservoir into the reactor as needed, and the aluminum is fed in a water slurry from a stirred reservoir using a peristaltic pump. The 


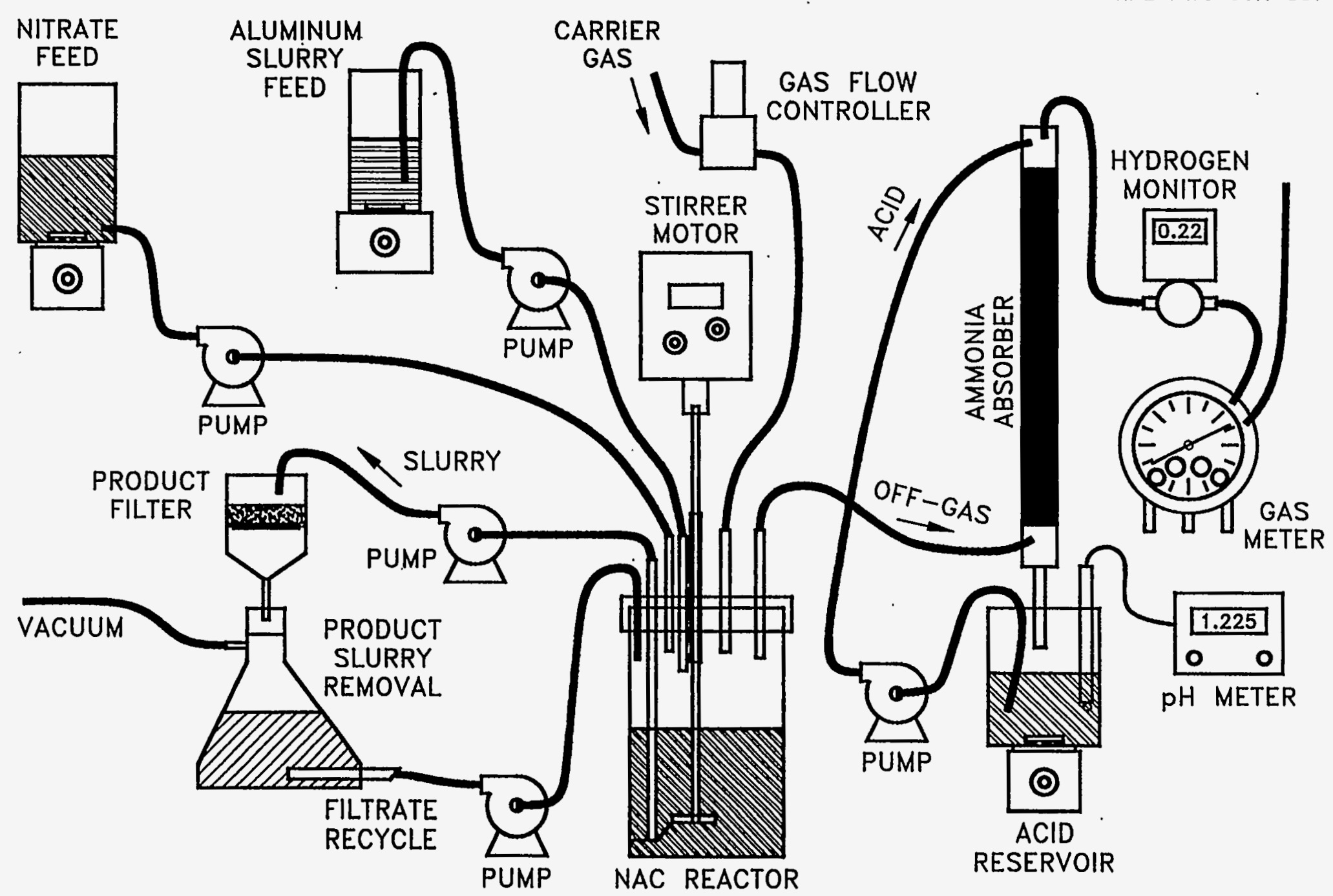

Fig. 4. Experimental apparatus for continuous laboratory NAC process. 
product slurry is removed from the reactor using another peristaltic pump and fed to a filtration flask with a Buchner funnel containing Whatman No. 2 filter paper. Filtrate can then be pumped back to the reactor to help maintain the water balance and return unreacted nitrate to the reactor. The filtrate can also be sampled at this point for nitrate, $\mathrm{pH}$, radioactivity, etc. The filtrate was analyzed for nitrate using the Method $418 \mathrm{~A}$ Ultraviolet Spectrophotometric Screening Method. ${ }^{11}$ When radioactive materials were used as tracers, they were counted on the $\gamma$-ray spectrometer to determine activity.

Tests on the solids included loose-packed and compressed density measurements. The loose-packed density was measured by tapping a known mass of powder into a graduated cylinder to measure the volume. The compressed density was achieved by compressing product powder using a 6.4-mm (1/4-in.)-diameter Parr pellet press with a $10-\mathrm{ksi}$ total uniaxial pressing capacity on the die punch. Pellets were formed using stearic acid $(\sim 5 \mathrm{wt} \%)$ as a lubricant and binder. The pellets were weighed, and the volume of water displaced by the pellet was measured to determine density.

\subsection{REACTOR OFF-GAS TREATMENT}

The ammonia is carried out of the test reactors by a nitrogen or argon purge through an ammonia scrubber. The scrubber is a 5-cm-ID column packed with $3 / 8$-in. ceramic Raschig rings. Dilute acid ( $1 \mathrm{~N} \mathrm{HCl}$ or $\left.1 \mathrm{~N} \mathrm{H}_{2} \mathrm{SO}_{4}\right)$ is pumped into the top of the column, and the gas flows upward from the bottom to contact the acid. The ammonia is produced at a rate of $1 \mathrm{~mol} / \mathrm{mol}$ nitrate reduced, and each liter of $1 \mathrm{~N}$ acid in the ammonia scrubber will neutralize $1 \mathrm{~mol}$ of ammonia. The $\mathrm{pH}$ of the acid and samples of the acid for titration were obtained from the reservoir. When the acid level in the reservoir gets low, additional acid can be added to lower the $\mathrm{pH}$ and scrub more ammonia. From the scrubber, the gas can be passed through a hydrogen monitor and then through a wet-test meter to monitor the volume of gas that has passed through the system. The hydrogen monitor is a Gasmaster 1 detector/controller with a flow-through hydrogen detector for gas stream analysis. It is specific for hydrogen and detects hydrogen concentrations ranging from $1 \mathrm{ppm}$ to $100 \%$. This instrument is manufactured by Crowcon (CEA Instruments, Emerson, NJ) and measures hydrogen based on the thermal conductivity difference between hydrogen and other gases in the reactor off-gas. Hydrogen thermal conductivity is an order of magnitude greater than other gases found in 
the reactor [197.1 $\mathrm{mW}(\mathrm{m} \cdot \mathrm{K})^{-1}$ for $\mathrm{H}_{2}$ vs 24.4 for $\mathrm{NH}_{3}, 28.5$ for $\mathrm{O}_{2}, 19.0$ for $\mathrm{Ar}, 27.5$ for $\mathrm{N}_{2}$, and 18.7 for water vapor].

\section{WASTE STREAMS EVALUATED BY THE NAC PROCESS}

Of the $\sim 242,000$ metric tons of nitrate waste stored at DOE facilities throughout the United States, the majority is stored in the 149 single-shell tanks located at Hanford. The Hanford SST waste is in the form of a salt cake. A synthetic waste, based on the mean concentrations of sludge components analyzed from core samples of 18 of the tanks, is presented in Table 1.9 Because sodium nitrate is the largest component in these tanks, processing of the salt cake/sludge will generate a supernate containing primarily sodium nitrate. Therefore, sodium nitrate solutions were used to run scoping studies on the NAC process. Following these initial studies, surrogates based on the salt cake composition presented in Table 1 were run.

Table 1. Composition of Hanford synthetic SST salt cake

\begin{tabular}{cc}
\hline Salt & Wt \% \\
\hline $\mathrm{NaNO}_{3}$ & 75.2 \\
$\mathrm{NaNO}_{2}$ & 4.8 \\
$\mathrm{Na}_{2} \mathrm{SO}_{4}$ & 2.4 \\
$\mathrm{Na}_{2} \mathrm{CO}_{3}$ & 4.3 \\
$\mathrm{NaAlO}_{2}$ & 4.3 \\
$\mathrm{Na}_{3} \mathrm{PO}_{4}$ & 4.6 \\
$\mathrm{NaOH}^{2}$ & 4.4 \\
Total & 100.0 \\
\hline
\end{tabular}


Supernates stored in the ORNL MVSTs also contain nitrate-based waste. Although the concentrations within the MVSTs vary, the mean sodium nitrate concentration is $4.4 M$ and sodium nitrate constitutes $-95 \%$ of the soluble salt in the tanks. ${ }^{10}$ Because actual samples of MVST W-26 supernate for 1985 characterization studies were available at ORNL for testing, samples of this waste were run to demonstrate the NAC process/product on waste containing radioactive and other components. Prior to using the actual W-26 samples, baseline studies were conducted on a W-26 surrogate. The surrogate used in these baseline studies, which was based on the 1985 supernate sampling and is documented in ORNL/TM-10218, is presented in Table 2.

Table 2. Surrogate representing MVST W-26 (1985) run

\begin{tabular}{lcc}
\hline Salt & $\begin{array}{c}\text { Concentration } \\
(\mathrm{g} / \mathrm{L})\end{array}$ & Molarity \\
\hline $\mathrm{NaNO}_{3}$ & 243.93 & 2.87 \\
$\mathrm{Na}_{2} \mathrm{SO}_{4}$ & 1.42 & 0.01 \\
$\mathrm{KNO}_{3}$ & 25.28 & 0.25 \\
$\mathrm{Ca}\left(\mathrm{NO}_{3}\right)_{2}$ & 57.43 & 0.35 \\
$\mathrm{Mg}\left(\mathrm{NO}_{3}\right)_{2} \cdot 2 \mathrm{H}_{2} \mathrm{O}$ & 90.33 & 0.49 \\
$\mathrm{NaCl}$ & 4.79 & 0.082 \\
\hline
\end{tabular}

${ }^{*}$ Adjust $\mathrm{pH}$ to $>12.5$ with $\mathrm{NaOH}$.

The supernate from W-26 was pretreated in 1989-90 to remove most of the cesium and strontium by ion exchange with ferrocyanide and sodium titanate. Then, the $\mathrm{pH}$ was reduced below 10.0, and the solids containing the ion-exchange materials were separated from the liquid. To prepare for the NAC process, the $\mathrm{pH}$ of the solution was raised to about 13 with concentrated sodium hydroxide to precipitate calcium hydroxide, which can form voluminous calcium aluminate in the process. The $\mathrm{pH}$ was checked with $\mathrm{pH}$ paper that had been checked against $0.1 M \mathrm{NaOH}$. The precipitate was settled and the supernate was decanted. Of the $133 \mathrm{~mL}$ starting volume of supernate, approximately $10-11 \mathrm{~mL}$ was left as solids and $119 \mathrm{~mL}$ was decanted for use in the NAC reaction. 
Since pretreatment conducted 1989-1990 had removed the cesium and strontium, radioactive tracers $\left({ }^{85} \mathrm{Sr}\right.$ and $\left.{ }^{137} \mathrm{Cs}\right)$ were added in some of the runs with the W-26 waste for gamma spectroscopy. The samples were counted using an intrinsic germanium detector (Princeton Gammatech) and an Accuspec multichannel analyzer computer data acquisition board (Canberra) in an IBM-XT computer with AccuSpec ASAP Radionuclide Analysis Software (Canberra) for data analysis. The counting system was calibrated using an efficiency standard (Standard Reference Material $4275 \mathrm{C}-88$ containing ${ }^{125} \mathrm{Sb},{ }^{154} \mathrm{Eu}$, and ${ }^{153} \mathrm{Eu}$ ) from NTIS.

\section{RESULTS AND DISCUSSION}

Batch tests with bench-scale continuous-stirred-tank reactors (CSTRs) were conducted to provide proof-of-principle information regarding the NAC process. Initial scoping studies were conducted using sodium nitrate solutions to gain experience with the equipment and process. The scoping tests were followed by waste-form evaluation studies designed to determine the suitability of the ceramic product as a final waste form. The batch CSTRs were used to provide materials for the waste-form evaluation studies, as well as to provide information regarding the process offgas. Following the batch tests, a benchscale CSTR system was designed, constructed, and operated to evaluate the process. The results from these studies are discussed in detail below.

\subsection{INITIAL SCOPING STUDIES}

Initial batch reactions were carried out in Pyrex beakers ranging in size from 25 to $1500 \mathrm{~mL}$. Various concentrations of sodium nitrate solutions were examined, and aluminum was added as a nonoxidized powder ( -325 mesh), water slurry ( -325 mesh), oxidized powder (powders from -200 to -325 mesh were used), or pellet form (up to $10 \mathrm{~mm}$ diam). The beaker contents were mixed with a stirring bar using a magnetic stirrer and heated on a laboratory hot plate. Cooling was accomplished by the addition of cold water into a pan surrounding the beakers.

Additional scoping studies were carried out in the bench-scale reactor system described in Sect. 3.1. A concentration of $1.7 M$ nitrate was used initially to make sure the product slurry was stirrable and pumpable; later tests used $3.4 M$ nitrate feed solutions. 
During these tests, the aluminum additions varied from stoichiometric quantities to 1.5 times stoichiometric [based on Eq. (1)].

The scoping studies were conducted to determine qualitative reaction rates, feasibility of feed configurations, and reaction control procedures and to gain experience in reactor operation and control. The findings made during the scoping studies are summarized below:

1. The $\mathrm{pH}$ of the nitrate-based waste must have a $\mathrm{pH}$ above 11 and preferably in the 1 to 13 range to initiate and sustain the reaction.

2. The desired reaction temperature is between 50 to $80^{\circ} \mathrm{C}$. Below $50^{\circ} \mathrm{C}$ the reaction is slow to start, and above $80^{\circ} \mathrm{C}$ it is difficult to control.

3. Aluminum particles smaller than 270 mesh tended to plug the feed line when fed as a powder, while aluminum particles from 60-130 mesh fed uniformly and predictably. Small particles (smaller than 270 mesh) could be fed as a slurry and offer the advantage of providing water required for the reaction. The size of the particle (i.e., the surface area) made a significant difference in the heat evolved after aluminum was added. Larger particles (25-30 mesh) evolved much less heat than the smaller particles. Additional testing is required to determine what size and shape of aluminum is best suited for the NAC process.

4. Using aluminum at quantities 1.5 times the theoretical requirement results in nitrate concentrations near zero.

5. It is important to maintain the concentration of aluminate in the reactor as high as possible. When the reactor solution becomes too dilute in soluble aluminate, the reaction rate decreases until the aluminate and aluminum-hydroxide concentrations are high enough to sustain the reaction.

6. Using previously produced gibbsite as a seed material for the reaction speeds the process. Without the gibbsite seed, an induction period of several hours may be required. 


\subsection{WASTE-FORM PREPARATION AND EVALUATION}

In some cases, the solid materials from the NAC bench-scale reactors were transported to the Metals and Ceramics (M\&C) Division for final waste-form preparation and evaluation.

The materials consisted of hydration products from the sodium nitrate and aluminum reaction. In some cases, these were physically combined with silica. The densification process used to prepare the final waste form is schematically shown in Fig. 5 . The initial step was to calcine the NAC product to remove most of the combined water. At temperatures up to $\sim 500^{\circ} \mathrm{C}$, the hydration products lose chemically combined water. The product at this stage is believed to consist of amorphous material possessing a high surface area. With further heating up to $\sim 900^{\circ} \mathrm{C}$, all of the combined water is lost, the surface area decreases, and crystallization begins. The materials at this point consist of agglomerated particulates. After calcination, the materials were lightly ground, pressed into pellets, and sintered. Heating rates were $-5-7^{\circ} \mathrm{C} / \mathrm{min}$ to the sintering temperature followed by an isothermal hold. Sintering temperatures ranged from $\sim 1200-1600^{\circ} \mathrm{C}$.

As an alternative to the above process, one sample was heated without the pressing to see if that step could be eliminated. Powder was poured into an alumina crucible and heated to $1400^{\circ} \mathrm{C}$ for $1 \mathrm{~h}$. The sample at this point was poorly densified and friable. The same sample was then heated to $1550^{\circ} \mathrm{C}$ for $1 \mathrm{~h}$. After this treatment, the material was melted and bonded to the bottom of the crucible.

After the waste form was prepared, it was evaluated by leach tests. The results of the preparation and leach testing of the NAC product are discussed in detail below.

\subsubsection{Waste-Form Preparation}

Three general classifications of NAC product were prepared for evaluation:

1. materials made from sodium nitrate with no silica added,

2. materials made from sodium nitrate with silica added, and

3. materials made from Hanford surrogate salt-cake solution with silica added.

These product samples were prepared using a quantity of aluminum sufficient to react with either $100 \%$ or $200 \%$ of the nitrate originally present in the starting solution 


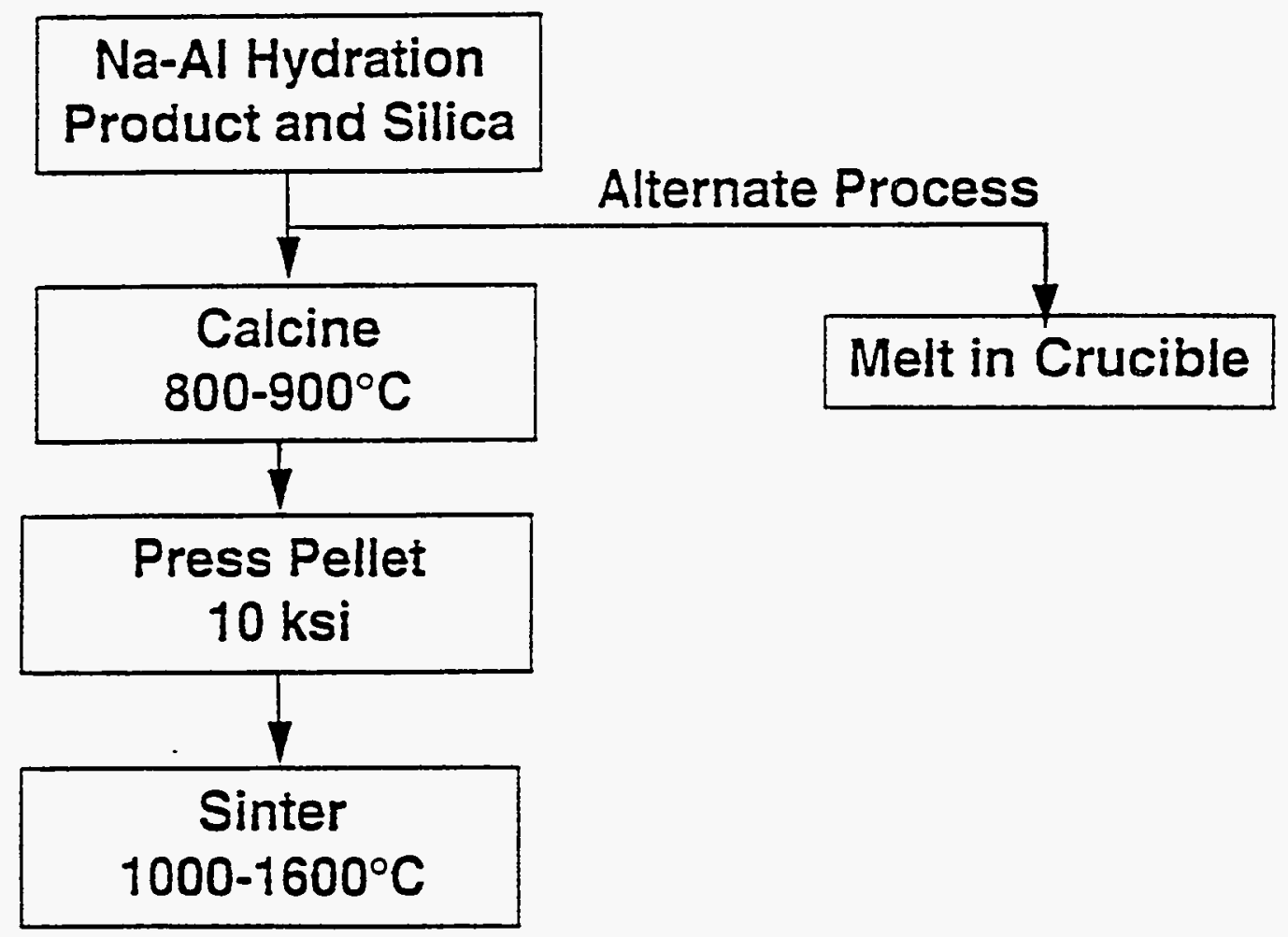

Fig. 5. Process for densification of NAC product. 
(3.1 $M$ nitrate). The excess aluminum reacts with water to form $\mathrm{Al}(\mathrm{OH})_{3}$ and hydrogen. When silica was added, it was added as $35-$ to $40-\mu \mathrm{m}$-sized quartz. The objective was to form nepheline $\left(\mathrm{Na}_{2} \mathrm{O} \cdot \mathrm{Al}_{2} \mathrm{O}_{3} \cdot 2 \mathrm{SiO}_{2}\right)$, which contains a $1: 1$ molar ratio of sodium to silica. The reactions were carried out at three different ratios of silica to sodium: $0.5,1.0$, and 1.5 moles silica to each mole of sodium present in the feed. Presented in Table 3 is a summary of the samples run, the source of the nitrate, the quantity of aluminum reacted, and the quantity of silica used. These samples were densified as described in Sect. 5.2. The calcination temperatures and the weight loss during calcination are also presented in Table 3. For reference, the densities that could theoretically be obtained if the samples were melted are also included. It should be noted that in samples AW6 and AW7, the silica was physically added to the product from the reactor; however, from visually examining the samples, it was apparent that the silica and the NAC product were not completely mixed. In all other samples (AW5, AW8-AW21), the silica was added to the reactor feed and there was no visible separation between the silica and NAC product.

The typical weight loss for a sample is presented in Fig. 6 . Up to $\sim 500^{\circ} \mathrm{C}$, the hydration products lose the chemically combined water. Further heating to $\sim 900^{\circ} \mathrm{C}$ removes all combined water, surface area decreases, and crystallization begins. Figure 7 shows the materials as agglomerated particulates.

As an alternative to the above process, one sample was heated without pressing to see if that step could be eliminated. Powder was poured into an alumina crucible and heated to $1400^{\circ} \mathrm{C}$ for $1 \mathrm{~h}$. The sample at this point was poorly densified and friable. The same sample was then heated to $1550^{\circ} \mathrm{C}$ for $1 \mathrm{~h}$, after which the material was melted and bonded to the bottom of the crucible. A reaction had occurred between the NAC product and the crucible material. From the phase diagram, reaction with the alumina crucible increases the refractory nature of the melted material and lowers the liquid phase content at high temperature. These results show that the NAC product is amenable to melting in an alumina crucible; however, reaction of the melt with the crucible material may limit the usefulness of this approach.

The densification results are summarized in Tables 4,5 , and 6 and shown graphically in Figs. 8 and 9. Several trends are apparent in the densification behavior of the various NAC products. As shown in Table 4, the samples containing no added silica showed very poor sintering, as is evidenced by the percent of theoretical density obtained, 
Table 3. NAC compositions used in densification study and calcination weight losses.*

\begin{tabular}{|c|c|c|c|c|c|c|}
\hline $\begin{array}{l}\text { Sample } \\
\text { No. }\end{array}$ & $\begin{array}{l}\text { Nitrate } \\
\text { source }\end{array}$ & $\begin{array}{c}\mathrm{Al}_{2} \mathrm{O}_{3} \\
\text { content } \\
\text { (\% theo) }\end{array}$ & $\begin{array}{c}\mathrm{SiO}_{2} \\
\text { content } \\
(\% \text { theo) }\end{array}$ & $\begin{array}{c}\text { Theoretical } \\
\text { density** } \\
\left(\mathrm{g} / \mathrm{cm}^{3}\right)\end{array}$ & $\begin{array}{c}\text { Calcination } \\
\text { temperature } \\
\left({ }^{\circ} \mathbf{C}\right)\end{array}$ & $\begin{array}{c}\text { Calcination } \\
\text { weight loss } \\
(\%)\end{array}$ \\
\hline AW-1 & $\mathrm{Na}$ & 100 & - & 2.8 & 900 & 35 \\
\hline AW-2 & $\mathrm{Na}$ & 100 & -- & 2.8 & 900 & 28 \\
\hline$A W-4$ & $\mathrm{Na}$ & 100 & -- & 2.8 & 900 & 37 \\
\hline AW-5 & $\mathrm{Na}$ & 200 & 100 & 2.8 & 900 & 40 \\
\hline AS-6 & $\mathrm{Na}$ & 100 & 100 & 2.6 & 900 & 38 \\
\hline AW-7 & $\mathrm{Na}$ & 100 & 150 & 2.6 & 900 & 36 \\
\hline AW-8 & $\mathrm{Na}$ & 100 & 50 & 2.7 & 850 & 32 \\
\hline AW-9 & $\mathrm{Na}$ & 100 & 100 & 2.6 & 850 & 36 \\
\hline$A W-10$ & $\mathrm{Na}$ & 100 & 150 & 2.6 & 850 & 31 \\
\hline AW-11 & $\mathrm{Na}$ & 200 & 50 & 3.0 & 850 & 47 \\
\hline AW-12 & $\mathrm{Na}$ & 200 & 100 & 2.8 & 850 & 45 \\
\hline AW-13 & $\mathrm{Na}$ & 200 & 150 & 2.8 & 850 & 37 \\
\hline AW-14 & Salt cake & 100 & 50 & 2.7 & 850 & 27 \\
\hline AW-15 & Salt cake & 100 & 100 & 2.6 & 850 & 25 \\
\hline AW-16 & Salt cake & 100 & 150 & 2.6 & 850 & 25 \\
\hline$A W-17$ & Salt cake & 200 & 50 & 3.0 & 850 & -- \\
\hline AW-18 & Salt cake & 200 & 100 & 2.8 & 850 & 42 \\
\hline AW-19 & Salt cake & 200 & 150 & 2.8 & 850 & -- \\
\hline $\mathrm{AW}-20$ & Salt cake & 100 & 100 & 2.6 & 850 & -- \\
\hline AW-21 & Salt cake & 100 & 100 & 2.6 & 850 & 22 \\
\hline
\end{tabular}

${ }^{*}$ The theoretical content is based on amount needed to form $\mathrm{Na}_{2} \mathrm{O} \cdot \mathrm{Al}_{2} \mathrm{O}_{3} \cdot 2 \mathrm{SiO}_{2}$ as the final phase.

${ }^{*}$ Used in calculations of sintered density. 


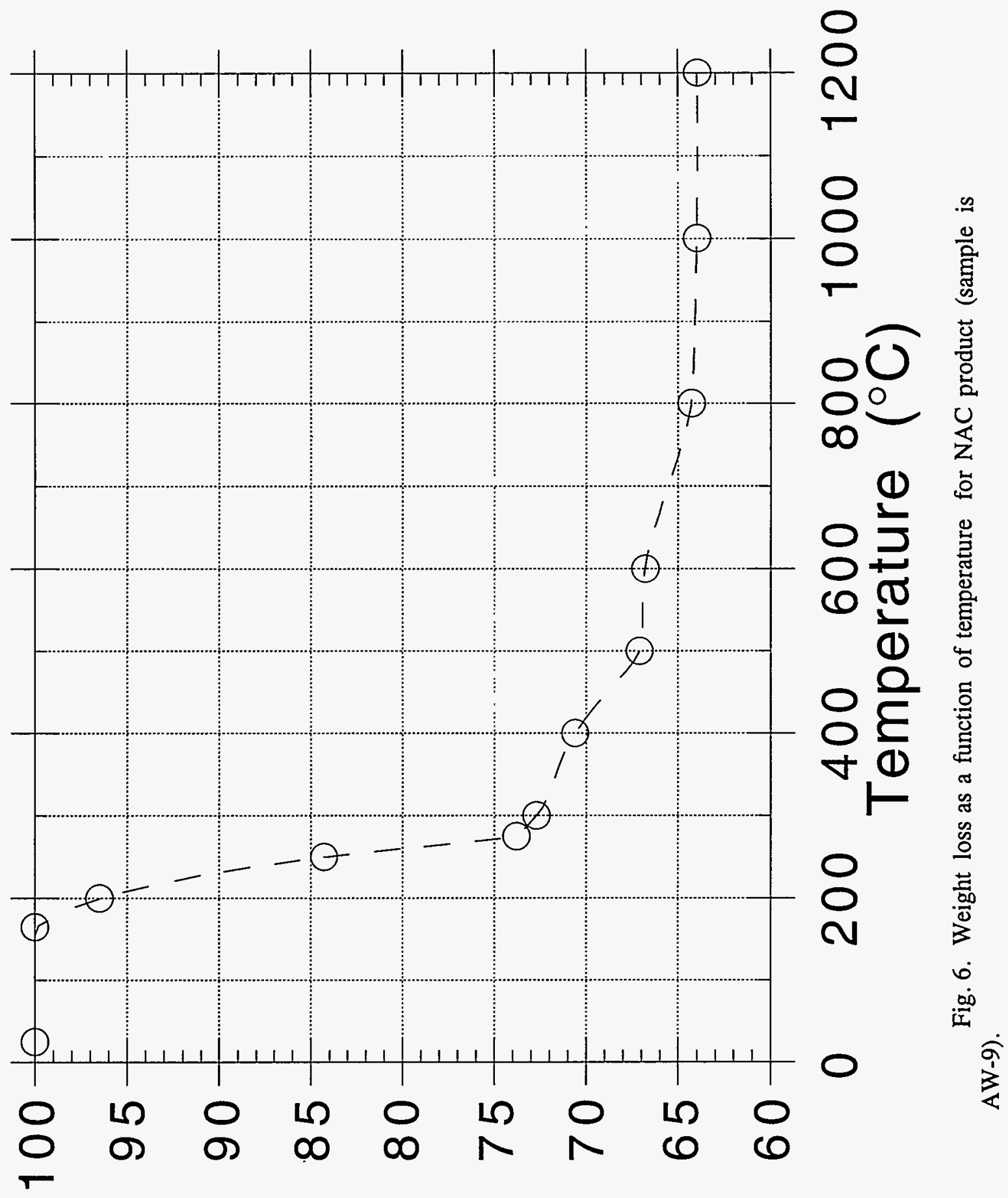

(\%) 5507 146ю!әм 


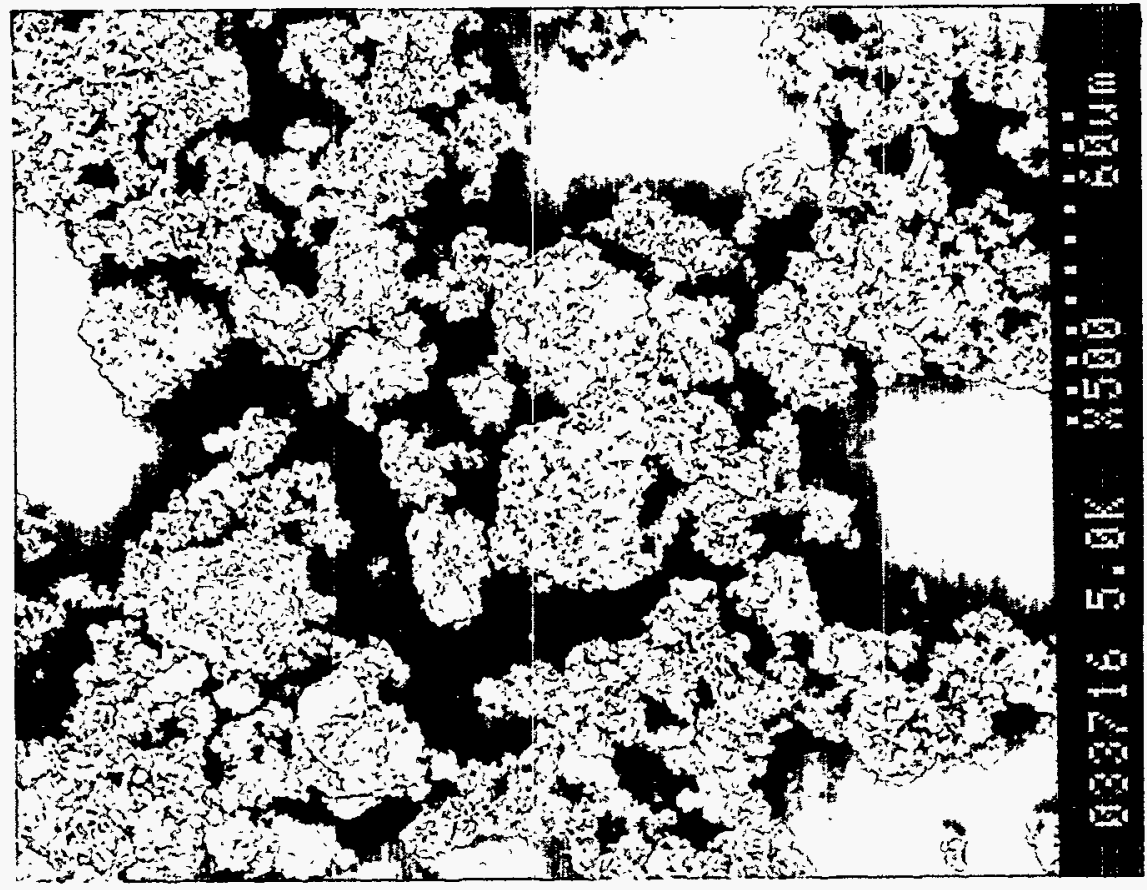

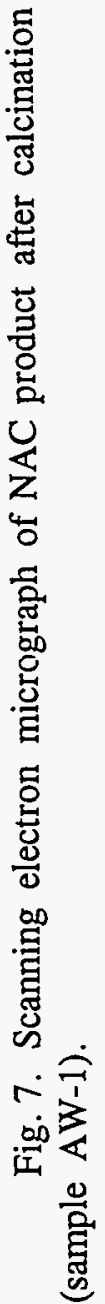

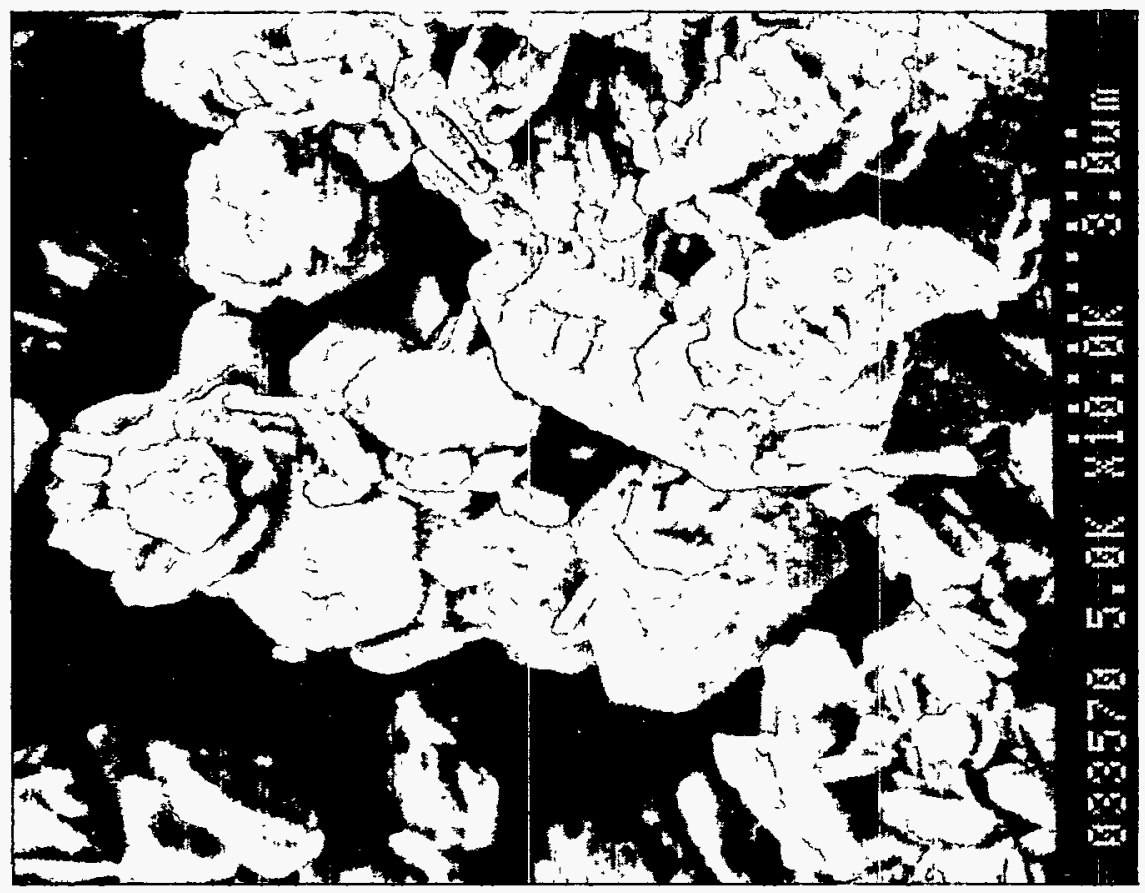


Table 4. Summary of densification results on materials made from sodium nitrate solution and containing no added silica: AW-1 through AW-4

\begin{tabular}{ccccc}
\hline Sample No. & $\begin{array}{c}\text { Green density } \\
\left(\mathrm{g} / \mathrm{cm}^{3}\right)\end{array}$ & $\begin{array}{c}\text { Sinter temperature } \\
\text { and time } \\
\left({ }^{\circ} \mathrm{C} / \mathrm{h}\right)\end{array}$ & $\begin{array}{c}\text { Sintered } \\
\text { density } \\
\left(\mathrm{g} / \mathrm{cm}^{3}\right)\end{array}$ & $\begin{array}{c}\text { Approximate } \\
\text { theoretical } \\
\text { density (\%) }\end{array}$ \\
\hline AW-1-1 & 1.0 & $1650 / 2$ & 1.1 & 39 \\
AW-2-1 & 0.9 & $1650 / 2$ & 1.0 & 36 \\
AW-4-1 & 1.4 & $1650 / 2$ & 1.4 & 50 \\
\hline
\end{tabular}


Table 5. Summary of densification results on materials made from sodium nitrate solution and containing silica additions:

AW-5 through AW-13

\begin{tabular}{|c|c|c|c|c|}
\hline Sample No. & $\begin{array}{l}\text { Green density } \\
\qquad\left(\mathrm{g} / \mathrm{cm}^{3}\right)\end{array}$ & $\begin{array}{l}\text { Sinter temperature } \\
\text { and time }\left({ }^{\circ} \mathrm{C} / \mathrm{h}\right)\end{array}$ & $\begin{array}{l}\text { Sintered density } \\
\left(\mathrm{g} / \mathrm{cm}^{3}\right)\end{array}$ & $\begin{array}{l}\text { Approximate } \\
\text { theoretical } \\
\text { density (\%) }\end{array}$ \\
\hline AW-5-1 & 1.6 & $1600 / 4$ & 2.7 & 100 \\
\hline AW-5-2 & 1.6 & $1550 / 2$ & 1.8 & 67 \\
\hline$A W-5-3$ & 1.6 & $1600 / 1$ & 2.1 & 78 \\
\hline AW-6-1 & 1.6 & $1600 / 4$ & Melt $^{*}$ & $\approx 100$ \\
\hline AW-6-2 & 1.6 & $1400 / 2$ & 1.8 & 72 \\
\hline AW-6-3 & 1.6 & $1550 / 2$ & Melt ${ }^{*}$ & $\approx 100$ \\
\hline$A W-6-4$ & 1.6 & $1450 / 1$ & 2.0 & 77 \\
\hline AW-7-1 & 1.5 & $1600 / 4$ & Melt $^{*}$ & $\approx 100$ \\
\hline AW-7-2 & 1.5 & $1400 / 2$ & Melt $^{*}$ & $\approx 100$ \\
\hline AW-7-3 & 1.5 & $1200 / 2$ & 1.6 & 66 \\
\hline AW-7-4 & 1.6 & $1300 / 1$ & 2.6 & 99 \\
\hline AW-8-1 & 1.3 & $1600 / 4$ & Melt $^{*}$ & $\approx 100$ \\
\hline AW-8-2 & 1.4 & $1400 / 2$ & 1.4 & 52 \\
\hline AW-8-3 & 1.4 & $1550 / 2$ & 2.4 & 86 \\
\hline AW-8-4 & 1.5 & $1550 / 1$ & 2.5 & 89 \\
\hline AW-9-1 & 1.3 & $1600 / 4$ & Melt $^{*}$ & $\approx 100$ \\
\hline AW-9-2 & 1.3 & $1400 / 2$ & 2.0 & 77 \\
\hline AW-9-3 & 1.3 & $1550 / 2$ & Melt $^{*}$ & $\approx 100$ \\
\hline AW-9-4 & 1.4 & $1450 / 1$ & 2.6 & $\approx 100$ \\
\hline AW-10-1 & 1.3 & $1600 / 4$ & Melt $^{*}$ & $\approx 100$ \\
\hline AW-10-2 & 1.3 & $1400 / 2$ & Melt $^{*}$ & $\approx 100$ \\
\hline AW-10-3 & 1.3 & $1200 / 2$ & 1.3 & 54 \\
\hline$A W-10-4$ & 1.3 & $1300 / 1$ & 2.5 & 96 \\
\hline AW-11-1 & 1.5 & $1600 / 4$ & 2.4 & 80 \\
\hline AW-11-2 & 1.4 & $1550 / 2$ & 2.3 & 77 \\
\hline AW-11-3 & 1.5 & $1600 / 1$ & 2.7 & 90 \\
\hline AW-12-1 & 1.3 & $1600 / 4$ & 2.8 & 100 \\
\hline$A W-12-2$ & 1.3 & $1550 / 2$ & 2.8 & 96 \\
\hline AW-12-3 & 1.3 & $1600 / 1$ & 2.8 & 100 \\
\hline AW-13-1 & 1.2 & $1600 / 4$ & Melt $^{*}$ & $\approx 100$ \\
\hline AW-13-2 & 1.2 & $1550 / 2$ & 2.8 & 95 \\
\hline AW-13-3 & 1.2 & $1550 / 1$ & 2.8 & 95 \\
\hline
\end{tabular}


Table 6. Summary of densification results on materials made from salt cake solution and containing silica additions: AW-14 through AW-21

\begin{tabular}{|c|c|c|c|c|}
\hline Sample No. & $\begin{array}{l}\text { Green density } \\
\qquad\left(\mathrm{g} / \mathrm{cm}^{3}\right)\end{array}$ & $\begin{array}{l}\text { Sinter temperature } \\
\text { and time }\left({ }^{\circ} \mathrm{C} / \mathrm{h}\right)\end{array}$ & $\begin{array}{l}\text { Sintered density } \\
\left(\mathrm{g} / \mathrm{cm}^{3}\right)\end{array}$ & $\begin{array}{c}\text { Approximate } \\
\text { theoretical } \\
\text { density (\%) }\end{array}$ \\
\hline AW-14-1 & 1.4 & $1450 / 1$ & 1.4 & 52 \\
\hline AW-14-2 & 1.4 & $1550 / 1$ & 1.5 & 56 \\
\hline AW-14-3 & 1.4 & $1600 / 1$ & Melt $^{*}$ & $\cong 100$ \\
\hline AW-15-1 & 1.3 & $1300 / 1$ & 1.4 & 54 \\
\hline AW-15-2 & 1.4 & $1400 / 1$ & 1.5 & 58 \\
\hline AW-15-3 & 1.3 & $1450 / 1$ & 1.9 & 73 \\
\hline AW-16-1 & 1.3 & $1150 / 1$ & 1.4 & 54 \\
\hline$A W-16-2$ & 1.3 & $1250 / 1$ & Melt $^{*}$ & $\cong 100$ \\
\hline$A W-16-3$ & 1.3 & $1200 / 1$ & 2.2 & 85 \\
\hline AW-17-1 & 1.3 & $1500 / 1$ & 1.9 & 63 \\
\hline AW-17-2 & 1.3 & $1600 / 1$ & 2.5 & 84 \\
\hline AW-17-3 & 1.3 & $1600 / 1$ & & \\
\hline AW-18-1 & 1.3 & $1450 / 1$ & 2.3 & 82 \\
\hline AW-18-2 & 1.3 & $1550 / 1$ & 2.3 & 82 \\
\hline AW-18-3 & 1.3 & & & \\
\hline AW-19-1 & 1.3 & $1400 / 1$ & 2.3 & 81 \\
\hline AW-19-2 & 1.3 & $1450 / 1$ & 2.3 & 82 \\
\hline AW-19-3 & 1.2 & $1450 / 1$ & 2.4 & 86 \\
\hline AW-20-1 & 1.3 & $1400 / 2$ & Melt $^{*}$ & $\cong 100$ \\
\hline AW-20-3 & 1.4 & $1300 / 1$ & 1.9 & 73 \\
\hline$A W-20-4$ & 1.4 & $1350 / 1$ & Melt $^{*}$ & $\cong 100$ \\
\hline$A W-20-5$ & & & & \\
\hline
\end{tabular}




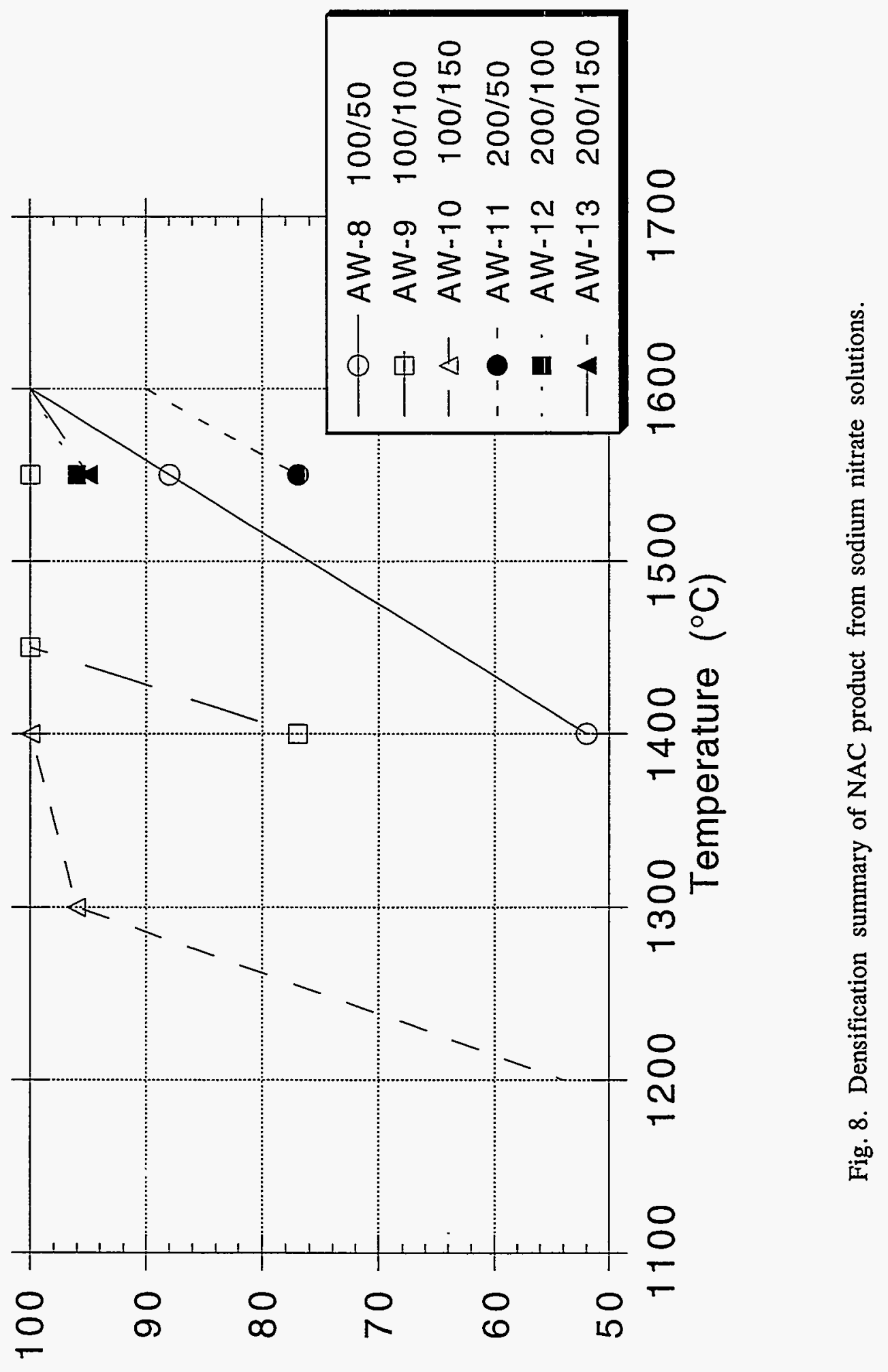

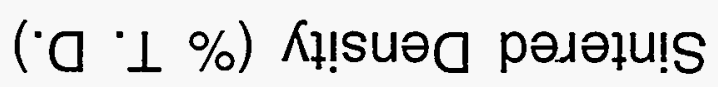




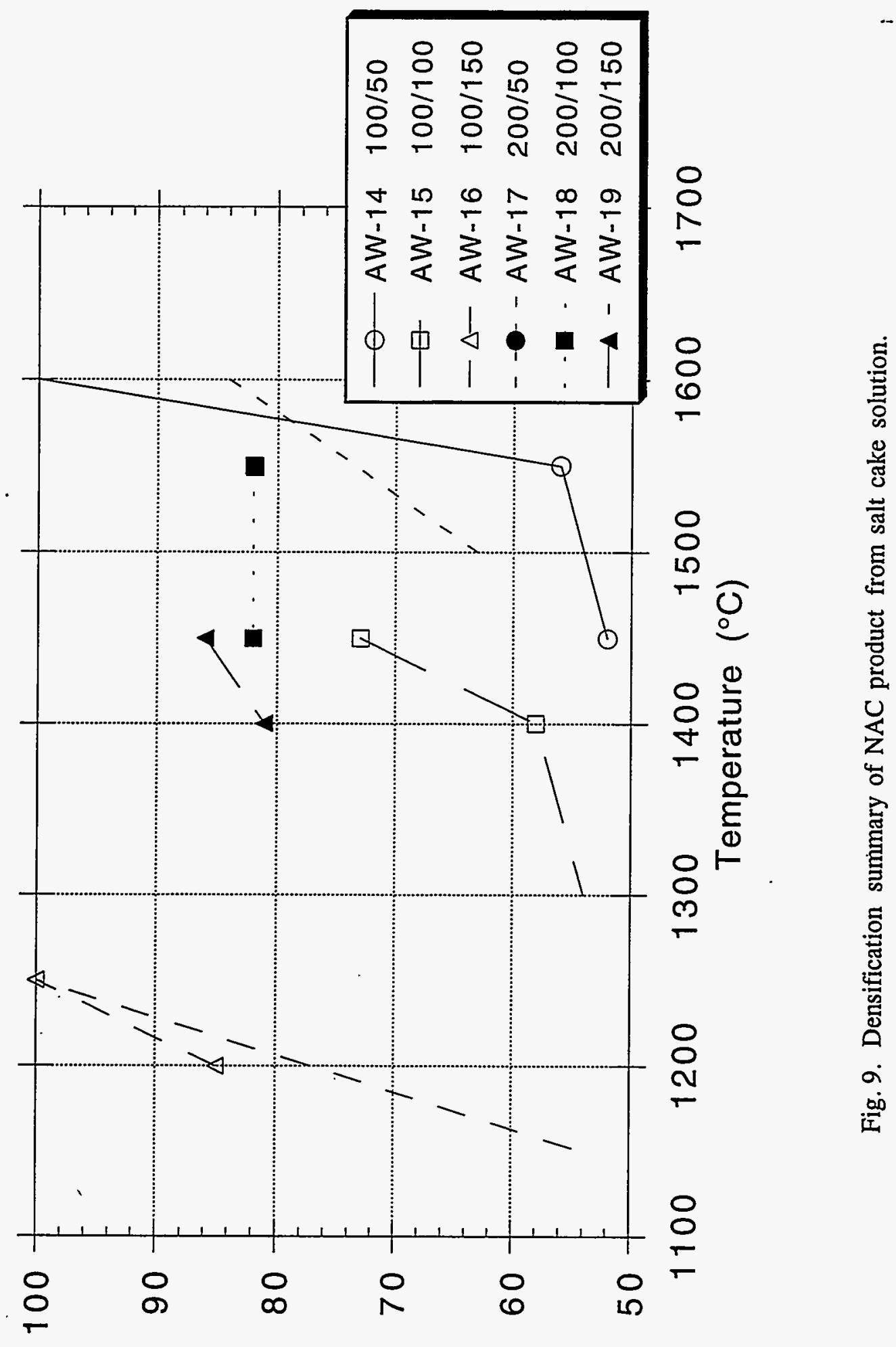

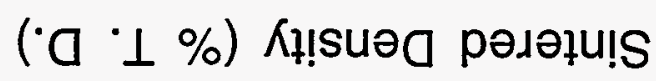


even when heated to temperatures of $1650^{\circ} \mathrm{C}$. Since sodium aluminate $\left(\mathrm{Na}_{2} \mathrm{O} \cdot \mathrm{Al}_{2} \mathrm{O}_{3}\right)$ has a melting point of $\sim 1870^{\circ} \mathrm{C}$ and is a fairly refractory material, silica was added to the later batches to lower the sintering temperatures needed for densification. In addition to lowering the sintering temperatures, it was found experimentally that the silica additions also improved the leaching behavior of the final product.

As shown in Figs. 8 and 9, the samples containing the theoretical amount of $\mathrm{Al}_{2} \mathrm{O}_{3}$ sintered to higher densities at lower temperatures. Also as the silica content was increased, densification at lower temperatures occurred. Comparing the densification between products from sodium nitrate and salt-cake solutions showed that except for the samples with $100 \% \mathrm{Al}_{2} \mathrm{O}_{3}$ and $150 \% \mathrm{SiO}_{2}(\mathrm{AW}-10$ and $\mathrm{AW}-16)$, the materials from the sodium nitrate solution densified at lower temperatures.

\subsubsection{Leach Testing}

Some of the waste forms produced by M\&C were subjected to leaching tests to determine how well the various waste products were bound in the ceramic material. Waste forms prepared from NAC reactor solids obtained after running both surrogate feeds and actual waste from MVST W-26 were tested using the Nuclear Regulatory Commission (NRC) American Nuclear Society (ANS) 16.1 leach test. ${ }^{12}$ The waste form for the surrogate waste was also tested by the Toxicity Characteristics Leaching Procedure (TCLP). ${ }^{13}$

For the ANS 16.1 testing of the surrogate product, samples of six different waste forms were prepared. A $4 M$ sodium nitrate solution was reduced in the NAC reactor. Three of the nitrate reductions used the theoretical amount of aluminum required to reduce the nitrate along with three different ratios of silica to sodium (i.e., 0.5:1,1:1, and 1.5:1 moles of silica per mole of sodium). The other three tests employed twice the quantity of aluminum theoretically necessary and the same silica-to-sodium ratios shown above. In all of these tests, the silica was added as $35-$ to $40-\mu \mathrm{m}$ quartz to the nitratebased waste solution prior to the addition of aluminum powder. The solids were oven dried at $105^{\circ} \mathrm{C}$, calcined at $800^{\circ} \mathrm{C}$, pressed into the shape of right circular cylinders at $10,000 \mathrm{psi}$, and sintered in a radiant heat tube furnace at $1225^{\circ} \mathrm{C}$. The final densified ceramic cylinders, which were on the average $1.3 \mathrm{~cm}$ long and had diameters of $1.7 \mathrm{~cm}$, were then leached following the NRC's ANS 16.1 leach test procedure. 
As shown from the data presented in Table 7, after $90 \mathrm{~d}$ of leaching, very little of the sodium present in the ceramic form containing the theoretical amount of aluminum and a molar ratio of silica to sodium of $1.5: 1$ could be released from these calcined and sintered samples. These ratios of aluminum to silica to sodium appear near an optimum and yet also contain a slight excess of silica present to bind other species soluble in the vitreous phase of the product. When these data are converted to an equivalent effective diffusion coefficient for sodium, a value of $10^{-16} \mathrm{~cm}^{2} \cdot \mathrm{s}^{-1}$ is obtained. This value is close to what might be expected from a glass waste form. The diffusion coefficient is equivalent to a leach index of 16.1 for sodium that is actually the negative logarithm of the effective diffusion coefficient.

Table 7. Ninety-day sodium cation leaching test results from ceramic forms of various Al:Si:Na ratios

\begin{tabular}{ccc}
\hline $\mathrm{All}_{\mathrm{NO}}{ }^{*}$ & $1: 1$ & $2: 1$ \\
\hline $\begin{array}{c}\text { Si:Na } \\
(M)\end{array}$ & \multicolumn{2}{c}{ Sodium extraction } \\
$(\%)$ & \\
\hline $0.5: 1$ & 14.710 & 12.094 \\
$1: 1$ & 0.277 & 0.501 \\
$1.5: 1$ & 0.017 & 0.049 \\
\hline
\end{tabular}

*Stoichiometric aluminum-to-nitrate ratio.

Since the ANS 16.1 leach test is really only directed at radioelements, if the sodium cation had been a radioelement, it would have been expected to have a minimum leach index of 6 or higher. As is apparent, a leach index of 16 is a factor of 10 times higher on this logarithmic scale or a factor of $10^{10}$ times better. Additionally, the fact that the ceramic form with the apparent optimum ratios of aluminum, silica, and sodium. contained 10.02 w/o sodium as $\mathrm{Na}$ and still achieved such impressive leaching resistance for very mobile sodium is notable. 


\subsubsection{Leaching NAC Product Produced from MVST-W-26 Supernate}

For the NRC's ANS 16.1 testing of actual radioactive waste, the product solids from the NAC reaction with W-26 supernate were dried at room temperature, mixed with $5 \mathrm{wt} \%$ stearic acid, and then pressed into pellets $6.4 \mathrm{~mm}$ in diameter and $9.5 \mathrm{~mm}$ long using a Parr tablet press in the hood. The three pellets were then sintered at $1250-1300^{\circ} \mathrm{C}$ utilizing microwaves. As the temperature passed through $650-750^{\circ} \mathrm{C}$ range, calcining took place and vapor could be seen leaving the pellets. These pellets were then weighed and measured to determine the surface area, volume, and mass. The results are shown in Table 8 . Each pellet was then counted to measure how much of each radioisotope was present before the leaching.

Table 8. MVST W-26 NAC pellets after calcining and sintering

\begin{tabular}{|c|c|c|c|c|c|}
\hline & Pellet 1: $0.369 \mathrm{~g}$ & & Pellet 2: $0.380 \mathrm{~g}$ & & Pellet 3: $0.301 \mathrm{~g}$ \\
\hline \multirow{5}{*}{ oval } & $10 \mathrm{~mm}$ long & & $10 \mathrm{~mm}$ long & & $8 \mathrm{~mm}$ long \\
\hline & $0.47625 \mathrm{~mm}$ major & oval & $0.47625 \mathrm{~mm}$ major & oval & $0.47625 \mathrm{~mm}$ major \\
\hline & $0.635 \mathrm{~mm}$ minor & & $0.635 \mathrm{~mm}$ minor & & $0.635 \mathrm{~mm}$ minor \\
\hline & $\begin{array}{l}1.76 \mathrm{~cm}^{2} \text { surface } \\
\text { area }\end{array}$ & & $\begin{array}{l}1.76 \mathrm{~cm}^{2} \text { surface } \\
\text { area }\end{array}$ & & $\begin{array}{l}1.41 \mathrm{~cm}^{2} \text { surface } \\
\text { area }\end{array}$ \\
\hline & $\begin{array}{l}17.6 \mathrm{~cm}^{3} \text { leach } \\
\text { volume }\end{array}$ & & $\begin{array}{l}17.6 \mathrm{~cm}^{3} \text { leach } \\
\text { volume }\end{array}$ & & $\begin{array}{l}14.1 \mathrm{~cm}^{3} \text { leach } \\
\text { volumes }\end{array}$ \\
\hline
\end{tabular}

These pellets were then leached according to the ANS 16.1 procedure in deionized water. The solutions were counted for several hours, and none of the ${ }^{85} \mathrm{Sr},{ }^{57} \mathrm{Co},{ }^{60} \mathrm{Co}$, and ${ }^{65} \mathrm{Zn}$ that could be detected in the pellets could be found in any of the leachates. However, ${ }^{137} \mathrm{Cs}$ was always found at concentrations just above the background level of the counter. The leaching results for ${ }^{137} \mathrm{Cs}$ is presented in Table 9.

The leach indices compare favorably with those reported above for the sodium cation leaching of the surrogate waste forms. The pellets produced from the MVST supernate were not completely densified, because they were not allowed to melt completely and lose the shape needed for the leaching studies. The leach indices have steadily increased with time (increasing resistance to leaching) and have ranged from $11+$ 
Table 9. Cesium-137 leaching results for MVST W-26 supernate

\begin{tabular}{|c|c|c|c|c|}
\hline $\begin{array}{l}\text { Leach interval } \\
\text { (h) }\end{array}$ & $\begin{array}{l}\text { Diffusion } \\
\text { coefficient* }\end{array}$ & $\begin{array}{l}\text { Interval leach } \\
\text { index }\end{array}$ & $\begin{array}{c}\text { Average } \\
\text { leach index }\end{array}$ & $\begin{array}{c}\text { Cumulative } \\
\text { leached } \\
(\%)\end{array}$ \\
\hline \multicolumn{5}{|c|}{ Pellet 1} \\
\hline 4 & $1.42 \mathrm{E}-12$ & 11.9 & 11.9 & 0.16 \\
\hline 25.5 & $1.02 \mathrm{E}-11$ & 11.0 & 11.4 & 0.89 \\
\hline 191 & $2.84 \mathrm{E}-12$ & 11.6 & 11.5 & 1.95 \\
\hline 552 & $2.71 \mathrm{E}-13$ & 12.6 & 11.7 & 2.41 \\
\hline 4992 & $6.27 \mathrm{E}-15$ & 14.2 & 12.2 & 2.50 \\
\hline \multicolumn{5}{|c|}{ Pellet 2} \\
\hline 4 & $4.43 \mathrm{E}-13$ & 12.4 & 12.4 & 0.09 \\
\hline 25.5 & $6.59 \mathrm{E}-13$ & 12.2 & 12.3 & 0.28 \\
\hline 191 & $2.81 \mathrm{E}-14$ & 13.6 & 12.7 & 0.38 \\
\hline 552 & $1.94 \mathrm{E}-14$ & 13.7 & 13.0 & 0.50 \\
\hline 4992 & $6.22 \mathrm{E}-16$ & 15.2 & 13.7 & 0.58 \\
\hline \multicolumn{5}{|c|}{ Pellet 3} \\
\hline 4 & $2.02 \mathrm{E}-13$ & 12.7 & 12.7 & 0.06 \\
\hline 25.5 & $1.45 \mathrm{E}-12$ & 11.8 & 12.3 & 0.34 \\
\hline 191 & $4.05 \mathrm{E}-13$ & 12.4 & 12.3 & 9.74 \\
\hline 552 & $3.87 \mathrm{E}-14$ & 13.4 & 12.6 & 0.91 \\
\hline 4992 & $3.46 \mathrm{E}-16$ & 15.5 & 13.3 & 0.97 \\
\hline
\end{tabular}

${ }^{*} \mathrm{~cm}^{2} / \mathrm{s}$.

to $13+$ for ${ }^{137} \mathrm{Cs}$, which is just slightly less than obtained in the sodium leach tests above. These numbers would actually be higher if an accurate surface area of the pellets were known. An estimate of the pellets' surface area was made based on the physical dimensions. Each pellet had more area than calculated because of the ribbed surface and holes and voids that could be seen. 
Results of the TCLP leach tests on NAC product that was dried but not thermally processed (unsintered) are presented in Table 10 in addition to those for thermally processed, sintered material. As the results show, the Environmental Protection Agency's (EPA's) TCLP test was passed for all hazardous species, although the product was not converted to the final ceramic form (i.e., the product from the reactor was only oven dried and not sintered to a glassy ceramic). These results are better than expected, for although it is known that the aluminate anion can form "highly" insoluble spinels with many metals and nonmetals, especially multivalent species, it was thought that perhaps formation of the ceramic form was necessary to pass this test.

Table 10. Toxicity characteristic leaching procedure (TCLP) test results of sintered and nonsintered reactor solids

\begin{tabular}{|c|c|c|c|}
\hline \multirow{2}{*}{$\begin{array}{l}\text { Hazardous } \\
\text { species }\end{array}$} & \multirow{2}{*}{$\begin{array}{c}\text { TCLP } \\
\operatorname{limit} \\
(\mathrm{mg} / \mathrm{L})\end{array}$} & \multicolumn{2}{|c|}{ Test results (mg/L) } \\
\hline & & Unsintered & Sintered \\
\hline Silver & 5 & 0.59 & 0.017 \\
\hline Arsenic & 5 & 0.44 & * \\
\hline Barium & 100 & 35.0 & 1.8 \\
\hline Cadmium & 1 & 0.067 & 0.010 \\
\hline Chromium & 5 & 0.24 & 0.093 \\
\hline Mercury & 0.2 & 0.032 & $*$ \\
\hline Lead & 5 & 0.73 & 0.11 \\
\hline Selenium & 1 & 0.20 & * \\
\hline
\end{tabular}

*Not present due to expected volatility.

\subsection{RESULTS OF CONTINUOUS REACTOR TEST}

A single continuous run over a 7-h period was conducted. Several important observations were made during the continuous run.

First, it appears possible to operate a continuous reactor for the reduction of nitrate to ammonia and gibbsite. It was also possible to maintain a low $(<250-1000 \mathrm{ppm})$ 
nitrate level in the reactor effluent with slightly more than the stoichiometric quantity of aluminum. With approximately $1 \frac{1 / 2}{2}$ times the stoichiometric ratio of aluminum to nitrate, less than $50 \mathrm{ppm}$ nitrate remained in the filtrate from the reactor.

Second, as observed in the batch test, the continuous run verified the importance of maintaining the concentration of aluminate and aluminum hydroxide in the reactor as high as possible to allow the reaction to proceed without delay. When the solution became too dilute in aluminate or hydroxide, the nitrate reduction reaction rate decreased until the aluminate and hydroxide concentrations reached a value high enough to again sustain the reaction. If sufficient nitrate was present, an attempt to increase the reaction rate by aluminum addition after it had decreased due to dilution resulted in an excessive amount of heat being produced. In addition, if the slurry became too thick, temperature control and gas/liquid separation were greatly hindered. When the slurry in the reactor was too thick, aluminum addition and the resulting reaction with nitrate tended to produce more foaming that carried over a large quantity of reactor material into the gas stream downstream of the reactor, and this could affect the ammonia absorption system.

\subsection{HYDROGEN PRODUCTION IN THE NAC PROCESS}

A batch reaction to determine hydrogen production was conducted using the same experimental setup as the continuous reactor with the addition of a hydrogen monitor in the off-gas stream. The reactor was started with a sodium nitrate feed, and no seed material was added. The aluminum was added in increments of $5-10 \%$ of the theoretical for converting the nitrate to ammonia. The purge gas for the system was argon, and a small ammonia trap was added about halfway through the run to remove the effect on the hydrogen monitor due to the presence of ammonia. The amount of hydrogen produced was calculated based upon the total gas flow recorded by the wet-test meter and the percent of that stream that was recorded as hydrogen. The gas flow was corrected for relative humidity, barometric pressure, and ammonia. The results are presented in Table 11 and graphically in Figs. 10 and 11. As shown, the overwhelming percentage of the hydrogen was produced during the last $30 \%$ of aluminum (i.e., between 120 and $150 \%$ of the theoretical aluminum required for complete conversion). This indicates that if the reactor were operated under conditions such that there is always nitrate present, little hydrogen gas should be produced. 
Table 11. Reaction to produce hydrogen

\begin{tabular}{lcccc}
\hline & $\begin{array}{c}\text { Last } 50 \% \\
\text { of added } \\
\mathrm{Al}\end{array}$ & \multicolumn{3}{c}{ Last three additions of Al } \\
\hline $\mathrm{Al}, \mathrm{g}$ & 11.57 & 1.50 & 1.69 & 1.22 \\
$\mathrm{Al}, \mathrm{mmol}$ & 0.43 & 0.06 & 0.06 & 0.05 \\
$\mathrm{H}_{2}, \mathrm{~L}$ & 5.21 & 0.46 & 1.36 & 1.51 \\
$\mathrm{H}_{2}, \mathrm{~mol}$ & 0.23 & 0.02 & 0.06 & 0.07 \\
$\mathrm{H}_{2}, \mathrm{~mol} / \mathrm{mol} \mathrm{Al}$ & 0.54 & 0.37 & 0.97 & 1.49 \\
& & & & \\
\hline
\end{tabular}


ORNL DWG 93A-854R

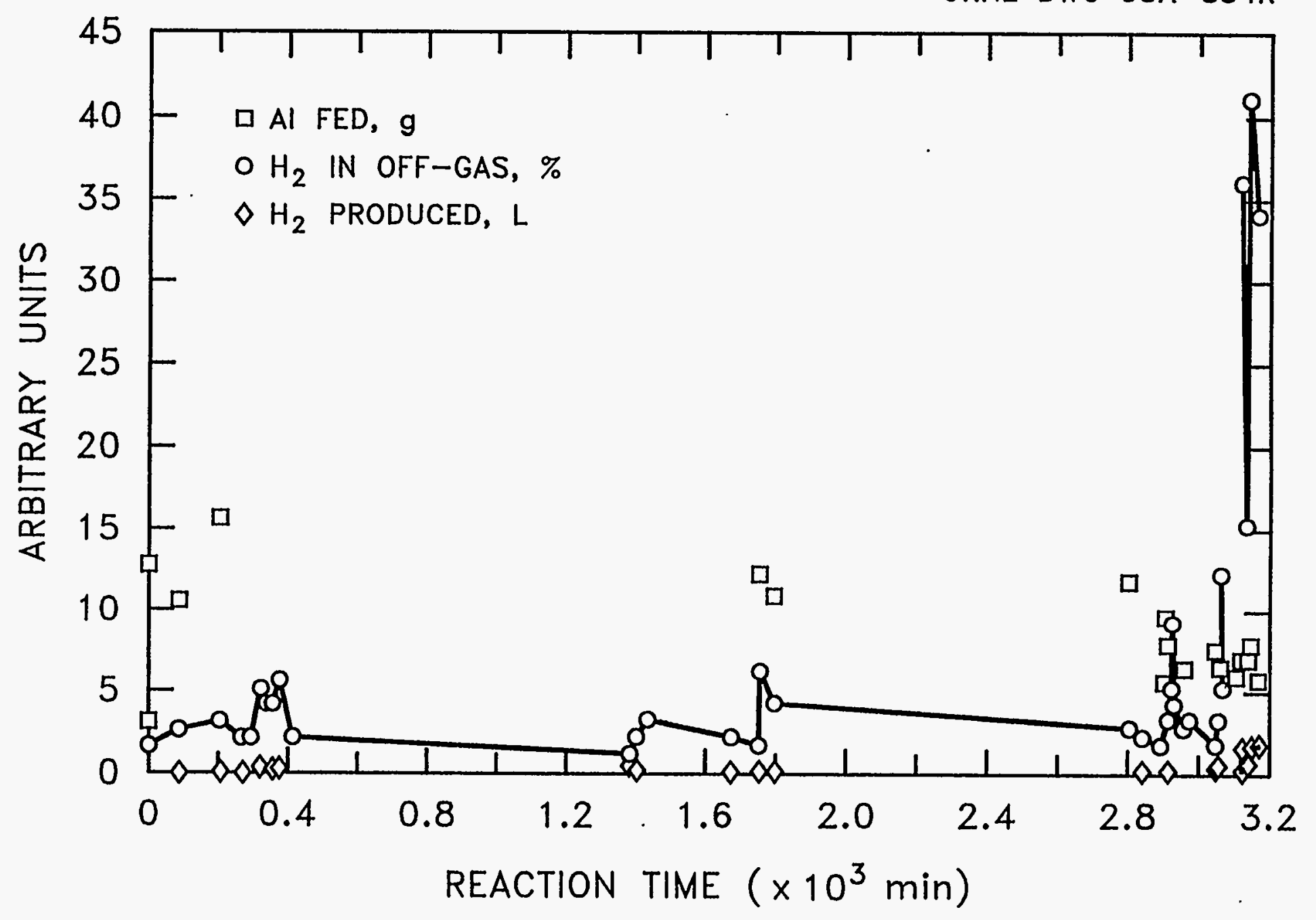

Fig. 10. Hydrogen production during NAC run. 
ORNL DWG 93A-855R

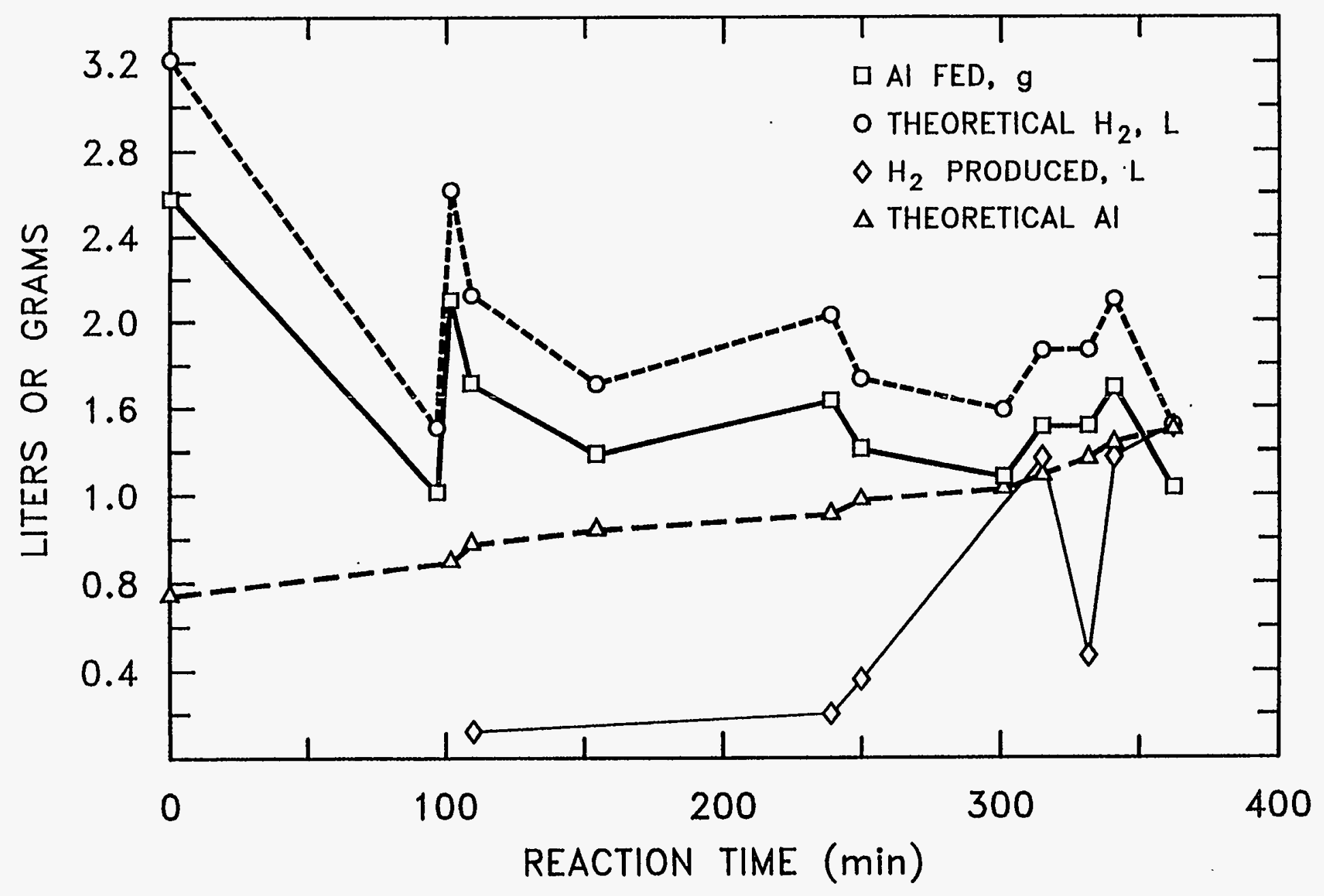

Fig. 11. Hydrogen production near the end of the reaction. 


\subsection{PILOT PLANT DEMONSTRATION}

The design of the equipment for a pilot demonstration of the nitrate destruction portion of the NAC process has been initiated. A diagram of the proposed pilot facility is presented in Fig. 12. The reaction will take place in a single-stage, stirred, backmix-type reactor. Crystalline silica powder will be added to the reactor in preparation for the final waste-form production step, or it may be added directly to the waste feed just prior to entering the reactor. A centrifuge and recycle system will be used for removing the solid reaction products (gibbsite, sodium aluminate, and silica) from the recycle steam. The reactor will be cooled by circulating slurry from the reactor through a heat exchanger. The off-gas from the reactor will be diluted with nitrogen and sent to off-gas scrubbing to remove ammonia. Design criteria for the glass or ceramic waste-form production portion of the process are being prepared by the Metals and Ceramics Division.

The initial design for the pilot plant used a basis of $1 \mathrm{~L}$ of $3.1 \mathrm{M}$ sodium nitrate Hanford salt cake per minute as the feed material. It should be noted that a unit smaller than $1 \mathrm{~L} / \mathrm{min}$ is also being considered. The following assumptions were made to develop the material balance flowsheet for the initial design of [i.e., 1-L/min feed of $3.1 \mathrm{M}$ (Hanford salt cake)] an NAC pilot plant. The material balance is shown in Fig. 13.

1. For the reduction of the nitrate, the stoichiometric reaction occurring:

$$
3 \mathrm{NaNO}_{3}+8 \mathrm{Al}+12 \mathrm{H}_{2} \mathrm{O} \rightarrow 3 \mathrm{NH}_{3} \uparrow+2.5 \mathrm{Al}_{2} \mathrm{O}_{3} \cdot 3 \mathrm{H}_{2} \mathrm{O} \downarrow+3 \mathrm{NaAlO}_{2} \text {. }
$$

2. For the reduction of the nitrite, the stoichiometric reaction occurring:

$$
2 \mathrm{NaNO}_{2}+4 \mathrm{Al}+6 \mathrm{H}_{2} \mathrm{O} \rightarrow 2 \mathrm{NH}_{3} \uparrow+2 \mathrm{NaAlO}_{2}
$$

3. Excess aluminum (10\%) produces hydrogen according to the following reaction:

$$
2 \mathrm{Al}+6 \mathrm{H}_{2} \mathrm{O} \rightarrow 3 \mathrm{H}_{2} \uparrow+\mathrm{Al}_{2} \mathrm{O}_{3} \cdot 3 \mathrm{H}_{2} \mathrm{O} \downarrow
$$

4. Sodium aluminate is in the form of $\mathrm{NaAlO}_{2} \cdot 2 \cdot 5 \mathrm{H}_{2} \mathrm{O}$. 


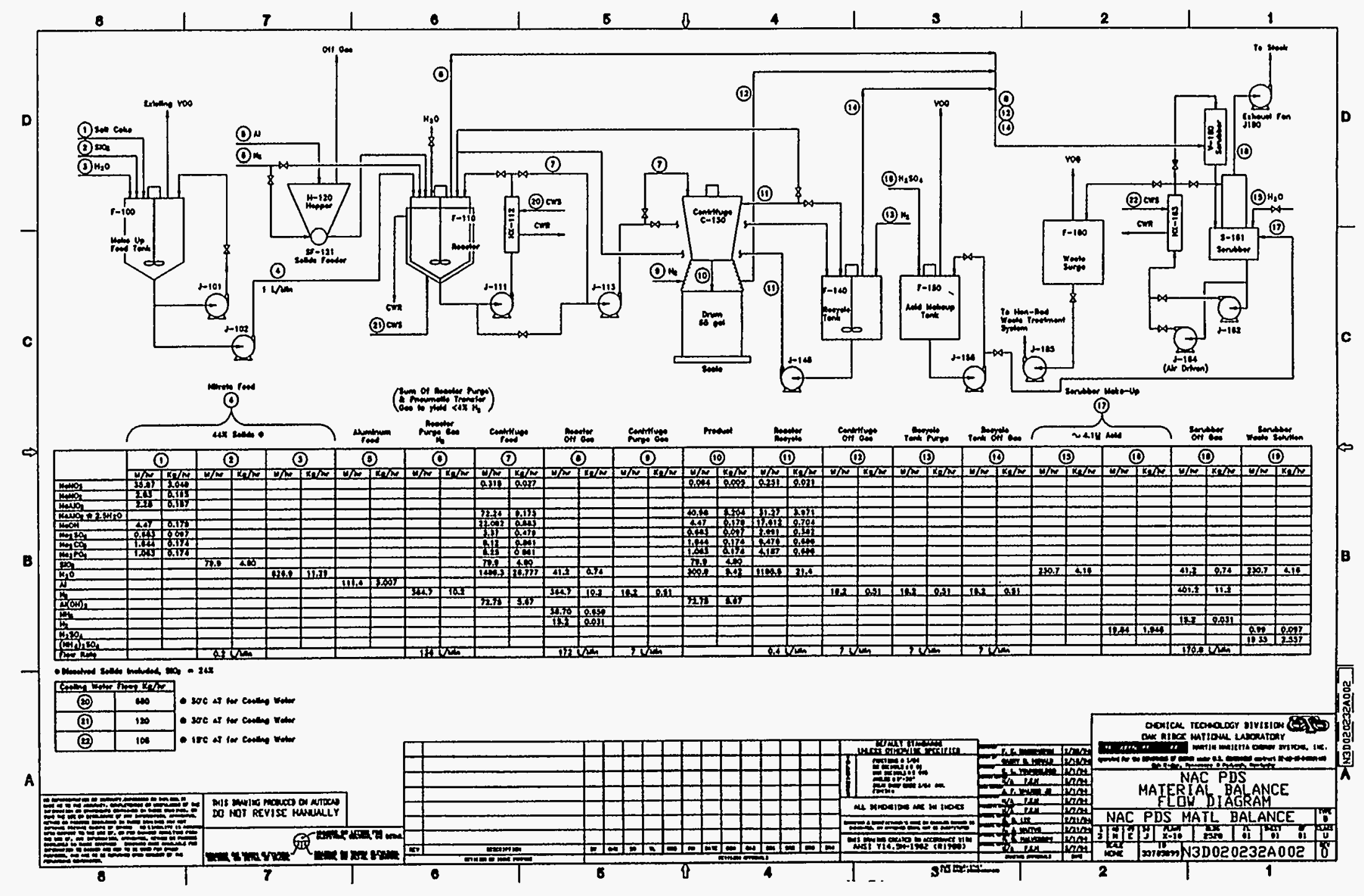

Fig. 12. NAC pilot demonstraton unit material balance and flow diagram. 


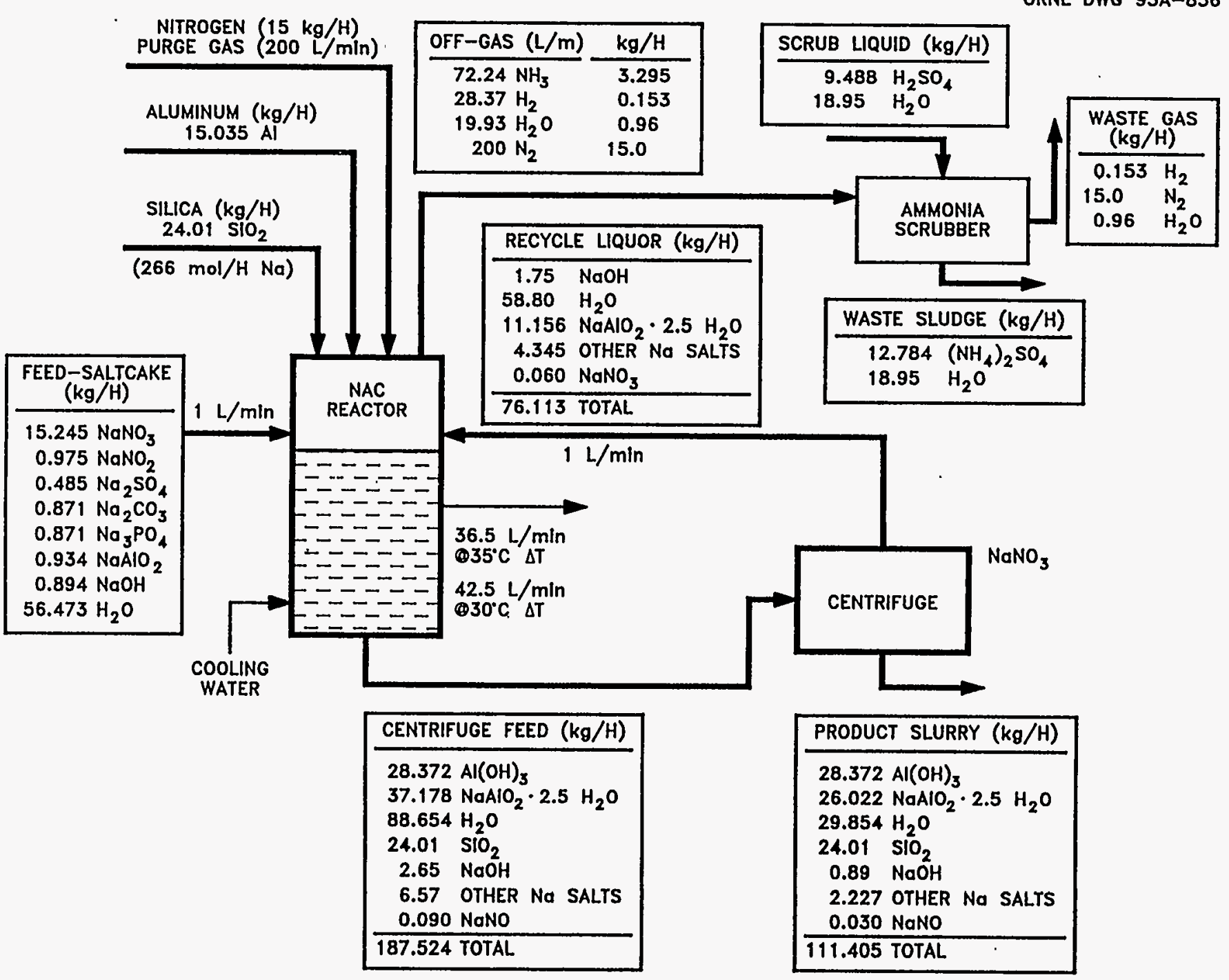

Fig. 13. Material balance flowsheet for the NAC pilot plant. 
For each hour of operation:

a. $179.4 \mathrm{~mol}$ of nitrate requires $478.3 \mathrm{~mol}$ aluminum and produces $298.9 \mathrm{~mol} \mathrm{Al}(\mathrm{OH})_{3}$ and $179.4 \mathrm{~mol} \mathrm{NaAlO}_{2}-2.5 \mathrm{H}_{2} \mathrm{O}$,

b. $14.1 \mathrm{~mol}$ nitrite requires $28.3 \mathrm{~mol}$ aluminum and produces $14.1 \mathrm{~mol} \mathrm{Al}(\mathrm{OH})_{3}$ and $14.1 \mathrm{~mol} \mathrm{NaAlO} 2 \cdot 2.5 \mathrm{H}_{2} \mathrm{O}$, and

c. The $10 \%$ excess aluminum (excess $=506.6 \times 110 \%-506.6=50.7 \mathrm{~mol} \mathrm{Al}$ ) reacts with water and produces $76.0 \mathrm{~mol} \mathrm{H}_{2}$ and $50.7 \mathrm{~mol} \mathrm{Al}(\mathrm{OH})_{3}$.

Thus far, the flowsheet, process and instrumentation drawings, and equipment layout drawings have been prepared for review. National Environmental Protection Agency (NEPA) documentation for the facility has been approved. Preparation of the safety documentation and the documentation required for waste disposal has been started. The types of equipment and instrumentation to be used for the major components have been selected for evaluation, and meetings have been held with vendors that can supply the components. Meetings have been held with Plant and Equipment Division personnel to estimate cost and schedule for installation of the equipment. Cost estimates and schedules have been prepared for the project. The schedule suggests that approximately 8 months would be required for construction and checking out the system after the major pieces of equipment to be installed are received. Critical path items include procurement of equipment such as the aluminum feeder and scrubber that may require up to 9 months delivery time.

\section{CONCLUSIONS}

The NAC process has been demonstrated on a bench scale in both batch and continuous reactors. These studies indicate that it is possible to maintain a low $(<1000 \mathrm{ppm})$ nitrate concentration in the reactor effluent with just slightly more than the stoichiometric quantity of aluminum $(-110 \%)$. Using this amount of aluminum to reduce nitrate corresponds to an efficiency of $90 \%$. With approximately $1 \frac{1}{2}$ times the stoichiometric ratio of aluminum to nitrate, less than $50 \mathrm{ppm}$ nitrate remains in the filtrate from the reactor. It is also important to maintain the concentration of aluminate in the reactor as high as possible and have aluminum hydroxide seed present to facilitate the 
reaction. When the reactor solution becomes too dilute in soluble aluminate, the nitrate reaction rate decreases.

The bench-scale studies conducted to date indicate that little hydrogen was produced during the initial reduction of nitrate. The overwhelming percentage of the hydrogen was produced during aluminum addition between 120 and $150 \%$ of the theoretical required for complete conversion, and after nearly all of the nitrate had been converted to ammonia. If the reactor was operated under conditions so that nitrate is always present, hydrogen gas production would be limited; therefore, the plan is to operate at $>1000 \mathrm{ppm}$ residual nitrate during continuous operations.

Waste-form studies performed with NAC reactor product from the bench-scale tests indicate that densification is highly dependent on the $\mathrm{Al}_{2} \mathrm{O}_{3}$ and $\mathrm{SiO}_{2}$ content. Increasing the $\mathrm{Al}_{2} \mathrm{O}_{3}$ content increases the sintering temperature, and increasing the $\mathrm{SiO}_{2}$ content decreases the sintering temperature. Silica additions are not only necessary for densification at temperatures $<1600^{\circ} \mathrm{C}$ but to bind sodium in the waste product. The high-density waste forms can be produced by the standard drying, calcining, pressing, and sintering techniques, as well as by melting the dried product in a crucible.

Leaching tests were also performed to evaluate the final waste forms. Results from ANS 16.1 leach tests of NAC product from a simulated sodium nitrate feed resulted in an effective diffusion coefficient of $10^{-16} \mathrm{~cm}^{2} / \mathrm{s}$ or a leach index of 16 for sodium over a 90-d period. Using actual radioactive low-level waste from ORNL's MVSTs for ANS 16.1 testing of radioelements ${ }^{85} \mathrm{Sr},{ }^{137} \mathrm{Cs},{ }^{60} \mathrm{Co}$, and ${ }^{65} \mathrm{Zn}$ resulted in nondetectable concentrations of all radioelements in the leachate over a 90-d period with the exception of cesium. The cesium leachates had leach indices ranging from 11 to 13 . These results were obtained with waste forms that contained a molar silica-to-sodium ratio of 1.5:1.

At present, the nepheline-glass ceramic formed corresponds to a nominal composition [based on reaction (6)] of $\mathrm{Na}_{2} \mathrm{O} \cdot(8.8) / 3 \mathrm{Al}_{2} \mathrm{O}_{3} \cdot 3 \mathrm{SiO}_{2}$ and sinters at $\sim 1200^{\circ} \mathrm{C}$. Based upon the volume of a $4 M$ sodium nitrate feed solution, a total volume reduction of $70 \%$ is achieved. For comparison, 1 volume of $5 M$ nitrate solution produces 0.28 volumes of glass (as per Westinghouse Hanford Company staff) or approximately a $70 \%$ volume reduction as well. ${ }^{14}$ Based upon the exact nominal composition above for sodium oxide, which actually accounts for $84 \%$ of the Hanford waste, a waste loading of 
$18 \%$ is obtained ( $15 \%$ if based on $0.84 \mathrm{Na}_{2} \mathrm{O}$ ). Aqueous alumina and phosphorous $\left(\mathrm{P}_{2} \mathrm{O}_{5}\right)$ accounts for an additional 8 and $6 \%$ of the waste, respectively.

Surrogate nitrate solutions spiked with eight hazardous metals were also run via the NAC process to evaluate the final waste product using EPA's TCLP. Both the sintered and raw product from the NAC reactor, even without being thermally processed to the glassy-ceramic form, passed the TCLP test.

\section{RECOMMENDATIONS}

Based on results obtained to date, scaleup of the NAC process should proceed as quickly as possible in order to meet the near- and long-term goals of the Hanford singleand double-shell tank waste treatment program. Additionally, kinetic and waste-form formulation work should also proceed to meet the stated goals of the Underground Storage Tank Integrated Demonstration program.

\section{ACKNOWLEDGMENTS}

This work is the result of efforts between two sections of the Chemical Technology Division, Engineering Development and Chemical Development, and members of the Metals and Ceramics Division at the Oak Ridge National Laboratory.

\section{REFERENCES}

1. A. J. Mattus, United States Patent 5,266,174,Nov. 30, 1993.

2. A. J. Mattus and D. D. Lee, The Nitrate to Ammonia and Ceramic (NAC) Process - $A$ Newly Developed Low-Temperature Technology, presented at the Second International Mixed Waste Symposium, Baltimore, MD, August 16-20, 1993.

3. P. E. Considine, Van Nostrand Reinhold Encyclopedia of Chemistry, 4th edition, Van Nostrand Reinhold Company, New York, NY, 1984. 
4. P. P. Budnikov, The Technology of Ceramics and Refractories, translation by Scripta Technica, The MIT Press, Cambridge, MA, Library of Congress card No. 64-7548, 1964.

5. L. H. Van Vlack, Elements of Material Science and Engineering, 5th ed., AddisonWesley Publishing Co., Reading, MA, p. 261, 1985.

6. A. J. Mattus et al., A Low-Temperature Process for the Denitration of Hanford SingleShell Tank, Nitrate-Based Waste Utilizing the Nitrate to Ammonia and Ceramic (NAC) Process, Phase I Report, ORNL/TM-12245, Oak Ridge National Laboratory, Oak Ridge, TN, October 1993.

7. D. M. Considine and G. D. Considine, Van Nostrand Reinhold Encyclopedia of Chemistry, 4th ed., pp. 605, 192, Van Nostrand Reinhold Company, New York, NY, 1984.

8. Communications with Salem Engelhard through Dr. Robert Yarrington, October 4, 1993.

9. E. Evans-Jones, Hanford Single Shell Tank Waste Preliminary Pretreatment Testing of Simulated Waste, 7th Annual DOE Model Conference on Waste Management and Environmental Restoration, September 1991.

10. D. D. Lee and D. O. Campbell, Treatment Requirements for Decontamination of ORNL Low-Level Liquid Waste, Oak Ridge National Laboratory, ORNL/TM-11799, October 1991.

11. Standard Methods for the Examination of Water and Wastewater, 16th ed., American Public Health Association, American Water Works Association, and Water Pollution Control Federation, publishers, Washington, DC, pp. 392-93, 1985.

12. American Nuclear Society, "Measurement of the Leachability of Solidified Low-Level Radioactive Wastes," 1981.

13. Toxicity Characteristic Leaching Procedure (TCLP), Federal Register, 51 (114), June 13, 1986.

14. Communication with Bruce A. Higley, Westinghouse Hanford Co., December 1, 1993. 